\title{
Economic information transmissions and liquidity between shipping markets: new evidence from freight derivatives
}

Article

Accepted Version

Creative Commons: Attribution-Noncommercial-No Derivative Works 4.0

Alexandridis, G., Visvikis, I. and Sahoo, S. (2017) Economic information transmissions and liquidity between shipping markets: new evidence from freight derivatives. Transportation Research Part E: Logistics and Transportation Review, 98. pp. 82-104. ISSN 1366-5545 doi:

https://doi.org/10.1016/j.tre.2016.12.007 Available at https://centaur.reading.ac.uk/68324/

It is advisable to refer to the publisher's version if you intend to cite from the work. See Guidance on citing.

To link to this article DOI: http://dx.doi.org/10.1016/j.tre.2016.12.007

Publisher: Elsevier

All outputs in CentAUR are protected by Intellectual Property Rights law, including copyright law. Copyright and IPR is retained by the creators or other copyright holders. Terms and conditions for use of this material are defined in the End User Agreement. 


\section{CentAUR}

Central Archive at the University of Reading

Reading's research outputs online 


\title{
Economic Information Transmissions and Liquidity between Shipping Markets: New Evidence from Freight Derivatives
}

\author{
G. Alexandridis ${ }^{a}$, S. Sahoo ${ }^{b}$ and I. Visvikis ${ }^{c}$
}

\begin{abstract}
Economic return and volatility spillovers of derivatives markets on a number of assets have been extensively examined in the general economics literature. However, there are only a limited number of studies that investigate such interactions between freight rates and the freight futures, and no studies that also consider potential linkages with freight options. This study fills this gap by investigating the economic spillovers between time-charter rates, freight futures and freight options prices in the dry-bulk sector of the international shipping industry. Empirical results indicate the existence of significant information transmission in both returns and volatilities between the three related markets, which we attribute to varying trading activity and market liquidity. The results also point out that, consistent with theory, the freight futures market informationally leads the freight rate market, though surprisingly, freight options lag behind both futures and physical freight rates. The documented three-way economic interactions between the related markets can be used to enhance budget planning and risk management strategies, potentially attract more investors, and thus, improve the liquidity of the freight derivatives market.
\end{abstract}

JEL Classification: C32; G13; G14

Keywords: Freight derivatives; options contracts; price discovery; volatility spillovers; liquidity; impulse responses.

Authors' names appear in alphabetical order

a, b ICMA Centre, Henley Business School, University of Reading, Whiteknights, Reading, RG6 6BA, UK.

${ }^{\mathbf{c}}$ World Maritime University, Fiskehamnsgatan 1, SE-211 18, Malmö, Sweden. 


\section{Introduction}

In a frictionless world, derivatives and underlying asset (physical) prices respond simultaneously to new market information and are thus perfectly correlated. In practice, however, there exist market frictions that can induce a lead-lag relationship between the two economic price series, allowing market participants to project the movements of the trailing market, based on new information transmitted by the leading market. Typically, derivatives contracts are more flexible and involve lower transaction costs than underlying physical contracts, facilitating a swifter adjustment of derivatives prices to new market information relative to underlying physical prices. Yet, the lack of a significant number of market participants in illiquid derivatives markets makes them less responsive to new information as it increases the cost of repositioning the contracts (see Capozza et al., 2004; and Löffler, 2005). This property is well documented in the general finance literature (see Fama and French, 1987; Sloan, 1996, among others) and has been extensively utilized by market practitioners.

The scope of investigating lead-lag relationships between different markets is a multifaceted one. First, it can provide insights on the inter-relationships between these markets, comparing their market efficiency levels, where the more efficient market absorbs new market information faster and transmits it to the least efficient market. Second, return spillovers from one market to another can be used as a price discovery vehicle, enabling practitioners to draw inferences for the price of the trailing market by observing price movements in the leading market. Gaining insight into future market prices is important since it can act as an effective anticipatory mechanism for market participants in the decision making process. Third, it can help draw inferences on volatility structures in order to hedge risk exposures. Market volatility projections can generally be based on: (i) the interaction of volatilities between the two markets; that is, if volatility transmissions exist between markets, a surge in market volatility of the informationally leading market indicates a possible increase in volatility of the trailing market (Ng, 2000; Baele, 2005); and (ii) a leverage effect; that is, a negative shock leads to greater volatility in the market relative to a positive shock of the same magnitude (Engle and $\mathrm{Ng}, 1993$ ). This study focuses on investigating the economic spillover effects between physical and several derivatives freight markets in the shipping industry.

The international shipping industry is characterized by global trade, large-scale capital investments, but also sizable operational and commercial risks, due to the significant volatilities in rates and prices. Shipping is the channel of world trade, connecting nations together and is widely regarded as the most efficient and inexpensive mode of transportation for all types of merchandise. According to the International Chamber of Shipping (ICS), around $90 \%$ of world trade is transported by more than 50,000 seagoing vessels. Commercial fleet is registered in over 150 nations and operated by over a 1.5 million seafarers of every nationality. According to a recent study for the European Community Shipowners' Associations (ECSA) the "overall contribution of the European shipping industry to the EU's Gross Domestic Products (GDP) in 2013 is estimated to have been $€ 147$ billion" (Oxford Economics, 2015). 
The international freight rate market is characterised by some unique features that differentiate it from other "soft" commodity markets. These are the high volatility, the seasonality effects associated with commodities transported by the ocean-going vessels, the cyclical behaviour of rates and prices following business cycles, and the non-storable nature of freight rates, amongst others (see Kavussanos and Visvikis, 2006b and Kavussanos and Visvikis, 2011). The nonstorable commodity nature of the underlying service in question is a distinct feature of freight derivatives and means that in this case the traditional cost-of-carry no-arbitrage arguments of fair pricing do not apply (see Kavussanos and Visvikis, 2004, Alizadeh, 2013, and Kavussanos, et al. 2014 , for more details).

This study extends previous research on price discovery in sea-going transportation markets in a number of ways. First, in light of the importance of the shipping industry and the inherent relationships between the derivatives and the physical markets in shipping, to the best of our knowledge, this is the first study that empirically assesses the information spillover of returns and volatilities between time-charter rates and corresponding freight futures and options prices, and provides direct evidence of price discovery in the freight options market. Freight futures/forwards are agreements between a buyer (typically charterers, hedging against freight rate increases) and a seller (typically shipowners, hedging against freight rate decreases) of freight services for a specific time in future but at a pre-agreed freight rate. These contracts are cash-settled at the maturity date of the contract against a settlement price. For all dry-bulk timecharter futures contracts investigated in this study, the settlement price is the average of all time-charter rates during the maturity month, as published by the Baltic Exchange.

Freight call or put options contracts are also cash-settled against a settlement price, and follow the same settlement average process as above (that is, they are Asian options), which can only be exercised on the last trading (settlement) day of the contracts (that is, they have a European style exercise). ${ }^{1}$ A distinct feature of freight options is that they can be seen as arithmetic price Asian options on the underlying freight rate market or, equivalently, as European options on futures/forward contracts. For Asian options the payoff is dependent on the average price of the underlying asset over some period of time before the settlement of the contract. Therefore, the first difference of Asian options with other options types is that they have lower volatility, and thus, are cheaper than European or American options. Typically, Asian options are written on underlying assets that have low trading volumes, and therefore, an average value of the underlying asset over a period of time is used as the settlement price, to avoid any possibility of price influence. Furthermore, for Asian options there are no analytical pricing formulas, as the assumption of lognormal price distribution does not hold. As a result, the following four options pricing models are typically used to price Asian options: (i) Kemma and Vorst (1990) propose a closed-form pricing model to geometric averaging price options; (ii) Turnbull and Wakeman (1991) suggest an analytical arithmetic form approximation with a lognormal

\footnotetext{
${ }^{1}$ For a detailed analysis of the freight derivatives market see Kavussanos and Visvikis (2006a, 2011).
} 
distribution; (iii) Levy (1992) extends the Turnbull-Wakeman analytical approximation and argue that Asian options should be estimated on a discrete time basis; and (iv) Curran (1992) develops an approximation for arithmetic Asian options based on a geometric conditioning framework (for more see Kavussanos and Visvikis, 2006a).

Freight derivatives contracts are traded Over-the-Counter (OTC) through various freight brokers and cleared in various clearing-houses (LCH.Clearnet, NOS Clearing, SGX Asia Clear, and CME Clearing Europe), but also trade in organized derivatives markets (NASDAQ OMX, ICE Futures Europe, and CME Group) and electronic trading screens (Cleartrade Exchange in Singapore, and Baltex in London). More specifically our investigation focuses on three major categories of dry-bulk vessels; namely Capesize (around 160,000 deadweight - dwt), Panamax (around 75,000 dwt) and Supramax (around 54,000 dwt) vessels. Although freight forward/futures prices have been found to informationally lead the underlying freight rates (Kavussanos and Visvikis, 2004; Spreckelsen et al., 2014; Zhang et al., 2014) and lag the commodity futures prices (Kavussanos et al., 2014), there exists no evidence on the interaction with freight options. ${ }^{2}$

Employing a research design that utilizes both futures and options derivatives allows us to highlight differences in price discovery between these two inter-related but yet distinct markets. Wang and Chen (2007) argue that major characteristics of options markets differ from futures and spot markets, such as the "diverse strategies involving call/put trading in options markets". They also argue that it is expected that informed traders would prefer to trade in options markets due to the opportunity to employ a greater degree of leverage and the inherent downside protection (maximum potential loss). Thus, in theory, one would expect that futures markets would fulfill their price discovery function, by attracting participants with both hedging and speculation trading motives, whereas participants in options markets would tend to concentrate on strategic risk hedging.

Second, this study examines for the first time whether the level of price discovery of freight futures and options markets has changed over time, and whether the degree/extent of information transmission between freight derivatives markets is related to concurrent market conditions, such as trading volume and open interest. Trading activities in derivatives markets play a critical role in price movements and information spillovers (Karpoff, 1987; Admati and Pfleiderer, 1988; Bessembinder, 1992; Bessembinder and Seguin, 1993; and Lee and Swaminathan, 2000). Bessembinder et al. (1996) argue that trading volume is related to the exogenous liquidity needs of the traders, all available information flows, cross-sectional differences in the opinions of traders, and the strategic interactions between traders with different information levels. Bessembinder and Seguin (1993) and Watanabe (2001), amongst others, report a significant positive relationship between price volatility and trading volume,

\footnotetext{
${ }^{2}$ In the literature, studies on freight options pricing have only been conducted (see Koekebakker et al., 2007; and Nomikos et al., 2013).
} 
and a significant negative relationship between price volatility and open interest. They conclude that these relationships may vary with changes in regulation. Chakravarty et al. (2004) argue that the price discovery of options markets is more pronounced when the trading volume of options is higher than that of the underlying asset.

Along these lines, this study also examines the effect of freight futures trading volume on timecharter rates, freight futures prices and freight options prices in order to offer a more in-depth understanding of the lead-lag relationships between the above related markets, and to assess the influence of trading activity on price fluctuations. In addition, market liquidity is important for the absorption of new market information since lower market liquidity can generate a higher illiquidity risk premium, and in turn lead to more pronounced market frictions and slower incorporation of information. In the freight derivatives market, the study of Alizadeh et al. (2015) is the only one examining the liquidity of freight futures contracts, using the Amihud illiquidity measure (Amihud, 2002). Although the freight options market is considered less liquid compared to the freight futures market based on trading volumes, there exists no study measuring the relative liquidity of freight options. ${ }^{3}$ In order to more effectively compare the relative liquidity of freight futures and options and gain a more in-depth understanding of the lead-lag relationship between these markets this study adopts the Amivest liquidity measure for both freight futures and options markets at different maturities. A link is established for the first time between the freight options market and its liquidity, as by attracting more investors in this market this could potentially reduce price volatility. Such a link corroborates earlier results by Kavussanos et al. (2004) that the introduction of freight derivatives trading decreased price volatility, had an impact on its asymmetry, and improved the speed of information flow in freight markets.

Third, this study uses a tri-variate GARCH model to capture the three-way price dynamics of futures, options and spot markets as well as the strength of information spillovers. Accordingly, we don't only provide evidence on price discovery channels, but also on the cross-market volatility spillover mechanisms given their importance for hedging, value at risk and options pricing (Wang and Chen, 2007). Unlike existing literature investigating futures and spot markets that pays little attention to the information spillovers associated with the options market, our approach allows for a more comprehensive modelling of all potential transmission channels. Gaining an understanding of options dynamics within such a tri-variate framework has practical implications for market makers when managing adverse selection risk and price discovery signals (Ehrmann et al. 2011).

Fourth, studying a rather recently established and emerging derivatives market serves the purpose of gaining insight on whether it is less efficient in assimilating new market information

\footnotetext{
${ }^{3}$ During the period of investigation, the total Capesize, Panamax, and Supramax futures traded cumulatively to around 2.1 million, 1.5 million and 390,000 lots, respectively, while Capesize, Panamax, and Supramax options counted to about 710,000, 87,000 and 6,000 lots, respectively, as reported by the Baltic Exchange.
} 
into prices compared to other more mature markets. Chiang and Fong (2001), Bae et al. (2004), and Chakravarty et al. (2004), among others, argue that in emerging markets traders may be less informed and significant market frictions and restrictions tend to exist, potentially leading to less efficient price discovery. Therefore, the information spillover mechanisms within the emerging freight derivatives market is an important empirical question that deserves further investigation.

Our results support the existence of significant information transmissions (both in returns and volatilities) between time-charter rates, freight futures and freight options markets for all three vessel types examined, indicating that new information is first absorbed into freight futures markets and subsequently spilled over to time-charter markets, before it is transmitted to freight options markets. Although freight futures contracts can be used as a price discovery vehicle for time-charter rates, freight options contracts cannot be relied upon to serve a price discovery function. These results can be at least partially attributed to the lower trading liquidity of the freight options market compared to freight futures market. It is also found that the spillover results uncovered here can generate on average economically profitable trading strategies.

This study has important practical implications for the shipping industry. First, practitioners (shipowners, charterers and investors, among others) can gain a better understanding of the interactions between three (non-storable) related markets, which can be used as a price discovery vehicle when taking positions in either physical or derivatives freight markets. The spillover results can be utilized in hedging and investment strategies, since by observing the informationally leading market (e.g. freight futures) shipowners and charterers can draw inferences of the future (short-run) direction of both the freight options and the physical freight markets. Second, the volatility interactions between the three related markets can provide an effective risk (volatility) prediction mechanism, which can enhance investors' decisionmaking. Accordingly, the volatility spillovers of freight derivatives markets can serve as a volatility discovery mechanism for shipowners and charterers to position themselves in the physical freight market, and thus, minimize their freight rate exposure more efficiently. Third, the study provides an analysis of liquidity risk for freight futures and options markets, over a wide range of maturities, which by attracting more market participants can possibly lead to an increase in market liquidity of the freight derivatives market. Further, the finding that the liquidity risk of freight derivatives contracts can adequately explain the documented spillover relationships between the three related markets can be utilized by practitioners, for hedging purposes, when taking positions in the physical as well as in the freight derivatives markets, improving their risk-return profile. Finally, the results of this study can act as a benchmark for researchers and regulators to gain a better understanding of the freight derivatives markets, and 
especially the freight options market, with the scope of developing better and more transparent pricing models, which could in turn potentially improve market liquidity and efficiency. ${ }^{4}$

The remainder of this study is organized as follows: Section 2 describes the properties of the data and methodology used along with the theoretical background. Section 3 presents the empirical results. Section 4 provides a discussion of the main findings and the economic significance of the results. Finally, section 5 concludes the study.

\section{Data and Methodology}

\subsection{Data}

This study utilises daily six-month Time-Charter Equivalent (TCE) rates, ${ }^{5}$ freight futures for different maturities and corresponding at-the money freight options prices and implied volatilities for three types of dry-bulk (Capesize, Panamax and Supramax) vessels, from April 2013 to August 2016 as reported by the Baltic Exchange. ${ }^{6}$ The Capesize four time-charter route basket, the Panamax four time-charter basket, and the Supramax six time-charter basket are used for underlying time-charter rates and derivatives (futures and options) prices. ${ }^{7}$ Corresponding trading volumes and open interest for freight futures and freight options contacts are collected from LCH.Clearnet. Although the Baltic Exchange initiated coverage of Baltic Freight Assessments (BFA, henceforth referred as freight futures) in January 2003 and Baltic Options Assessments (BOA) in January 2008 for all dry-bulk vessel types, comprehensive trading volume data (daily trading activities with respect to various maturities) for freight futures and options are available from LCH.Clearnet only after April 2013. BFAs are mid bid-ask FFA prices for several contract maturities ahead, while BOA are average daily

\footnotetext{
${ }^{4}$ For more information on the practical implications of information spillovers in the freight derivatives market, in terms of design of investment portfolios, asset pricing and risk management see Kavussanos et al. (2014).

${ }^{5}$ TCE rates are calculated by taking voyage revenues, subtracting voyage expenses and then dividing the total by the round-trip voyage duration in days.

${ }^{6}$ Near-month, second near-month, near-quarter, second near-quarter, third near-quarter, near-calendar year and second near-calendar year contracts are used. Near month/quarter/year contracts signify contracts starting in near month/quarter/year and settle in the next month/quarter/year, respectively. Second near-month/quarter/year contracts signify contracts starting in the second following month/quarter/year and settle in the second next month/quarter/year, respectively, and so on. A perpetual contract rollover technique is used at the last trading day of the month/quarter/year, to avoid price jumps at the expiration period of the derivatives contracts.

${ }^{7}$ Though the Capesize 2014 five time-charter route basket attracts more trading interest at the time of writing, this study uses the Capesize four time-charter route basket as the investigated sample is from April 2013, while the Capesize 2014 basket is available only from February 2014. The Capesize time-charter basket comprises of the following equally weighted average routes: C8_03 (Gibraltar/Hamburg transatlantic round voyage), C9_03 (Continent/Mediterranean trip China-Japan), C10_03 (China-Japan transpacific round voyage) and C11_03 (China-Japan, redelivery ARA or passing Passero) routes. The Panamax time-charter basket comprises of the following equally weighted average routes: of P1A_03 (Skaw-Gibraltar transatlantic round voyage), P2A_03 (Skaw-Gibraltar trip to Taiwan-Japan), P3A_03 (Japan-South Korea transpacific round voyage) and P4_03 (Japan-South Korea trip to Skaw Passero) routes. The Supramax time-charter basket comprises of the following routes: S1A (Antwerp - Skaw trip to Singapore-Japan) 12.5\%, S1B (Canakkale trip to Singapore-Japan) 12.5\%, S4A US (Gulf trip to Skaw-Passero) 12.5\% and S4B (Skaw-Passero trip to US Gulf) 12.5\% routes each and S2 (South Korea -Japan, one Australian or Pacific round voyage) 25\% and S3 (South Korea-Japan trip to SkawGibraltar) $25 \%$ routes.
} 
assessments of implied volatility for at-the-money freight options, as provided by the respective panels of freight derivatives brokers (panelists) appointed by the Baltic Exchange. The option's implied volatility is the theoretical volatility based on the option's quoted price. ${ }^{8}$ For the days in the sample period where the Baltic Exchange does not produce a TCE rate, the corresponding freight futures and options prices are also excluded. Also all models are estimated with the full sample (Jan 2008 - Aug 2016), without the sample restriction of the trading volume variable, in order to capture a complete shipping business cycle and include the effects of the global financial crisis. The results are qualitatively the same to the ones reported here and are available upon request. In order to further investigate if the information spillover results are time-varying over different time periods, we split our sample in three different periods: (a) full sample (Jan 2008 - Aug 2016), (b) Pre-sample (Jan 2008 - Apr 2013), and (c) Post-sample (Apr 2013 - Aug 2016). Again, the results are qualitatively the same with the results in the ensuing analysis, and for the sake of brevity are not reported here, but are available upon request.

Since freight options have freight futures as their underlying asset they are calculated using Black (1976) pricing model, using at-the-money implied volatility with a Turnbull and Wakeman (1991) approximation (see Nomikos et al., 2013). ${ }^{9}$ At-the-money option prices are used in this study to avoid any underpricing and overpricing from out-of-money and in-themoney options, respectively, which can lead to biased results when investigating information transmissions (see Wiggins, 1987 for more details). The main price drivers of options are the following: (i) the Delta of an option measures how much its price is expected to change per $\$ 1$ change in the price of the underlying asset. For at-the-money options (like the ones in this study) the Delta should be very close to 0.50 as the trading value is about the same for both calls and puts; (ii) the Theta of an option measures the rate of change in an option's price given a unit change in the time to expiration. At-the-money options have a higher time value and a higher decay rate that out-of-the-money or in-the-money options; (iii) the Vega of an option measures the amount of the option's price changes with an increase in volatility. Since at-themoney options have the greatest amount of time value, they also have higher Vegas than outof-money and in-the-money options; and (iv) the Rho of an option measures the amount by which the price of an option changes to a unit increase in the risk-free interest rate. Overall, all above price drivers have been taken into consideration in the estimation of option prices in this study.

The OTC nature of freight derivatives markets makes it difficult to obtain trading volume and open interest data for all maturities. The Baltic Exchange collects weekly trading volume and open interest data from different clearing-houses, although the data are not segregated based

\footnotetext{
${ }^{8}$ The brokers providing data for BFA and BOA prices are: BRS Brokers, Clarkson Securities Ltd., Freight Investor Services Ltd., GFI Brokers, Pasternak Baum \& Company Inc., and Simpson Spence \& Young Ltd.

${ }^{9}$ The Turnbull and Wakeman (1991) approximation assumes a lognormal distribution under arithmetic averaging, while the first and second moments of the averaging process are used to evaluate the options contracts.
} 
on maturities but are cumulated for each vessel type, which could potentially lead to biased results (for example, the number of Capesize freight futures contracts traded in a week is presented as an aggregate of all different contract maturities). ${ }^{10}$ Thus, the trading volume and open interest from LCH.Clearnet are used instead since: (i) they are based on vessel types and contract maturities, and (ii) this specific clearing-house captures more than half of the cleared freight derivatives market. ${ }^{11}$

\subsection{Stationarity and cointegration}

The order of integration (stationarity) of each price series is determined by the Augmented Dickey and Fuller (ADF, 1981), Phillips and Perron (PP, 1988) and Kwiatkowski et al. (KPSS, 1992) unit root tests. More recent studies argue that a variable could exhibit a stationary behavior preceding and following a structural break point while being non-stationary for the whole sample period (see Perron and Vogelsang, 1992). In this study, a unit root test with one structural break is also employed for price series that are endogenous variables in the system, following the work of Perron and Vogelsang (1992), Banerjee et al. (1992) and Vogelsang and Perron (1998).

Johansen (1988) standard cointegration tests are also conducted to assess whether there exist long-run (cointegrating) relationships between the endogenous variables. When there exists evidence of long-run (cointegrating) relationships the following Vector Error Correction Model (VECM) is estimated:

$$
\Delta X_{t}=\prod X_{t-1}+\sum_{i=1}^{p-1} \Gamma_{i} \Delta X_{t-i}+\varepsilon_{t} ; \quad \varepsilon_{t} \mid \Omega_{t-1} \sim \operatorname{distr} .\left(0, H_{t}\right)
$$

where, $X_{t}$ is a $3 \times 1$ vector $\left(S_{t}, F_{t}, O_{t}\right)$ ' of logarithmic time-charter rates, freight futures and freight options prices, respectively; $\Delta$ denotes the first-order difference operator; and $\varepsilon_{t}$ is a $3 \times 1$ vector of error-terms $\left(\varepsilon_{S, t}, \varepsilon_{F, t}, \varepsilon_{O, t}\right)$ ' that follows a conditional distribution of zero mean and time-varying covariance matrix $\left(H_{t}\right) . \prod X_{t-1}$ denotes the error-correction term (linear combination of non-stationary $S_{t}, F_{t}$ and $O_{t}$ prices exhibiting a stationary property), where $X_{t-1}$ represents lagged $S_{t}, F_{t}$ and $O_{t}$ prices, and $\prod$ represents the coefficient of $X_{t-1}$. If the rank of $\Pi$ is 2 there exist 2 cointegrating vectors, and if the rank of $\Pi$ is 1 there exist 1 cointegrating vector. This also determines the presence of long-run relationships between the variables, and the expression $\prod X_{t-1}$ represents the error-correcting vector(s).

Perron (1989) argues that although variables can be stationary, a shock can change their behavior. Similarly, Johansen et al. (2000) state that if no cointegrating vector exists between two or more non-stationary variables this does not explicitly imply non-existence of long-run

\footnotetext{
${ }^{10}$ From LCH.Clearnet, Inter Continental Exchange (ICE), NOS Clearing, and SGX Asia Clear clearing-houses.

11 The weekly average trading volume of Capesize time-charter futures contracts as reported by the Baltic Exchange and LCH.Clearnet is 11,837 lots and 7,102 lots, respectively, during the post-sample period. The weekly average open interest of Capesize time-charter contracts as reported by the Baltic Exchange and LCH.Clearnet is 143,667 lots and 97,667 lots, respectively, during the sample period.
} 
relationships between them, but rather points to non-existence of long-run relationships in the absence of a structural break. Therefore, if the standard Johansen (1988) test fails to determine any cointegrating relationships between the variables, then the Johansen et al. (2000) approach is adopted to test for cointegration with one structural break among the $S_{t}, F_{t}$ and $O_{t}$ variables. ${ }^{12}$

\subsection{Return and volatility spillovers}

Spillover effects in returns between Capesize, Panamax and Supramax time-charter rates and their corresponding freight futures and freight options prices are investigated using the following VECM model:

$$
\begin{aligned}
& \Delta S_{t}=q_{s} e c t_{t-1}+\sum_{i=1}^{p} C_{s_{-} s}^{i} \Delta S_{t-i}+\sum_{i=1}^{p} C_{f_{-} s}^{i} \Delta F_{t-i}+\sum_{i=1}^{p} C_{o_{-} s}^{i} \Delta O_{t-i}+a_{s} R_{t-1}+\varepsilon_{t}^{s} \\
& \Delta F_{t}=q_{f} e c t_{t-1}+\sum_{i=1}^{p} C_{s_{-} f}^{i} \Delta S_{t-i}+\sum_{i=1}^{p} C_{f_{-} f}^{i} \Delta F_{t-i}+\sum_{i=1}^{p} C_{o_{-} f}^{i} \Delta O_{t-i}+a_{f} R_{t-1}+\varepsilon_{t}^{f} \\
& \Delta O_{t}=q_{o} e c t_{t-1}+\sum_{i=1}^{p} C_{s_{-} o}^{i} \Delta S_{t-i}+\sum_{i=1}^{p} C_{f_{-} o}^{i} \Delta F_{t-i}+\sum_{i=1}^{p} C_{o_{-} o}^{i} \Delta O_{t-i}+a_{o} R_{t-1}+\varepsilon_{t}^{o} \\
& e_{t}^{j} \mid \Omega_{t-1} \sim \text { distr. }\left(0, H_{t}\right)
\end{aligned}
$$

where, $\Delta S_{t}, \Delta F_{t}$ and $\Delta O_{t}$ are logarithmic first-difference time-charter rates, freight futures, and freight options prices, respectively; $e c t_{t-1}$ is the lagged error-correction term, which represents the long-run relationship between the time-charter rates and their derivatives prices; $e_{t}^{j}$ are stochastic error-terms with zero mean and time-varying covariance matrix $H_{t}$; and $C_{m \_n}^{i}$ (where, $m=s, f$, $o$ and $n=s, f$, $o$ with $m \neq n$ ) indicate short-run spillover relationships, $R_{t-1}$ represents the one-period lagged ratio of trading volume over open interest of futures contracts, capturing the effect of freight futures trading activities on time-charter rates, futures prices, and options prices if $a_{s}, a_{f}$ and $a_{o}$, respectively, are statistically significant. ${ }^{13}$

If the coefficient $C_{m \_n}^{i}$ is non-zero and statistically significant, a unidirectional causal relationship exists from market $m$ to market $n$, indicating that market $m$ Granger causes market $n$. A bi-directional (feedback) effect in returns exists if two (or more) $C_{m \_n}^{i}$ terms in the system (with $m \neq n$ ) are statistically significant. Causality relationships are tested applying a standard Wald test on the joint significance of the lagged estimated coefficients of $C_{m \_n}^{i}$. A standard VECM model is estimated if cointegration is found using the Johansen (1988) test. If cointegration is not found using Johansen (1998) test, then we test for the existence of a longrun relationship with one structural break using Johansen et al. (2000) test and also estimate a

\footnotetext{
12 Though Johansen et al. (2000) allows for cointegration with two structural breaks, this study tests only for a cointegration with one structural break due to not sufficient sample length. Moreover, the Johansen et al. (2000) test can account for multiple cointegrating terms, and as such is suitable for evaluating cointegration relationships between three variables (i.e. time-charter, futures and options), where the rank of the variables could be greater than one. Other cointegration tests, such as the one by Gregory and Hansen (1996), are restricted to only test for a single cointegrating term between two variables, and as such, are not suitable here.

${ }^{13} s, f$ and $o$ represent time-charter rates, freight futures and freight options, respectively.
} 
VECM augmented with exogenous terms in order to capture the change in properties due to the structural break. ${ }^{14}$

If no cointegration is found, a Vector Autoregression (VAR) model is estimated, excluding the $e c t_{t-1}$ term from Equations (2a), (2b) and (2c). The order of the variables in the VAR models is based on the decreasing exogeneity of the variables. Since derivatives prices are derived from the underlying assets, the physical time-charter rates are considered first in the ordering of the VAR models. Then, given that freight options are priced with futures as the underlying assets, futures prices are economically more exogenous than options prices. Therefore, the used order here of the VAR models considers time-charter rates first, followed by freight futures prices, and then by freight options prices. However, robustness tests are conducted with five different VAR orders for the three endogenous variables and for seven different maturities, totalling to 35 different VAR models for the Capesize vessels. The parameter results (not reported, but are available upon request), including coefficients, standard deviations and Wald tests, remain inline to the VAR models with the aforementioned order, and as such, different orders seem not to affect the ensuing results.

Furthermore, impulse response functions are estimated to provide a detailed insight of the spillover relationships in returns of the investigated variables, by measuring the reaction of one market (say, time-charter) to one standard deviation shock generated at any of the other two markets (say, freight futures and freight options). The VAR and VECM models are estimated as Seemingly Unrelated Regressions (SUR), where Generalized Impulse Response (GIR) are applied in order to overcome the issues induced by the orthogolalization of the shocks through Cholesky decomposition of the covariance matrix of Equation (1) (see Kavussanos and Visvikis, 2004). ${ }^{15}$

The conditional second moments (variance) of time-charter, freight futures and freight options prices are estimated using the following Generalized Autoregressive Conditional Heteroskedasticity (GARCH) model, as in Engle and Kroner (1995), generally known as Baba Engle Kraft and Kroner (BEKK) GARCH, to ensure a positive definite covariance matrix and to significantly decrease the number of parameters to be estimated:

$$
H_{t}=A^{\prime} A+C^{\prime} \varepsilon_{t-1} \varepsilon_{t-1}^{\prime} C+D^{\prime}\left(\varepsilon_{t-1}<0\right)\left(\varepsilon_{t-1}^{\prime}<0\right) D+B^{\prime} H_{t-1} B
$$

where, $A, C, D$ and $B$ are (3x3) diagonal coefficient matrices, representing the constant, the lagged coefficient of the error-term, the lagged coefficient of the asymmetric error-term (only

\footnotetext{
${ }^{14}$ The change at the structural break point arise because of a change in the trend or shift in regime or both. This is captured by adding a dummy variable (zeros before the structural break and ones after the structural break) and a trend as exogenous variables.

${ }^{15}$ A SUR system is used to impose restrictions (i.e. providing one standard deviation shock) to one variable and understand how the other variables are reacting to that shock in the different equations in the system.
} 
negative errors), and the lagged conditional volatility coefficient, respectively. A restricted BEKK GARCH is the following:

$$
h_{j j, t}=a_{j}+\left(c_{j j} \varepsilon_{t-1}^{j}\right)^{2}+\left(d_{j j} \varepsilon_{t-1}^{j}\left(\forall \varepsilon_{t-1}^{j}<0\right)\right)^{2}+\left(b_{j j}\right)^{2} h_{j j, t-1}
$$

where, $j=s, f, o$, with a conditional covariance equation:

$$
h_{i j, t}=c_{i i} c_{j j} \varepsilon_{t-1}^{i} \varepsilon_{t-1}^{j}+d_{i i} d_{j j} \varepsilon_{t-1}^{i}\left(\forall \varepsilon_{t-1}^{i}<0\right) \varepsilon_{t-1}^{j}\left(\forall \varepsilon_{t-1}^{j}<0\right)+b_{i i} b_{j j} h_{i j, t-1}
$$

where, $j=s, f, o$ and $i=s, f, o$ with $i \neq j$.

In the above model, as the number of estimated parameters increases the number of iterations in the process also increase, which can lead to non-convergence of the estimation process, and hence, failure in the parameter estimation. To overcome this issue we estimate a restricted BEKK GARCH model using a Quasi-Maximum Likelihood (QML) approximation. Moreover, other GARCH specifications could also be applicable, like the Dynamic Conditional Correlation (DCC)-GARCH, although they require a large sample of observations for the QML estimation to be maximised and for all parameters to be estimated.

In the finance literature, the choice between BEKK-GARCH and DCC-GARCH models is relevant when producing forecasts of volatility spillovers, where the former models are mainly used for forecasting conditional covariances, while the latter models are preferred when forecasting conditional correlations. Since this research does not involve the forecasting of spillovers, the choice of GARCH models is rather immaterial. However, as a robustness test, we have also estimated the models using DCC-GARCH with a sample of 2,164 usable observations (Jan 2008 - Aug 2016), yielding similar results (not reported, but available upon request) with the ones reported the ensuing analysis using a sample of 849 usable observations (Apr 2013 - Aug 2016). Such results are in line with Caporin and McAleer (2008), which state that BEKK-GARCH and DCC-GARCH models perform similarly for parameter estimations. For the latter sample, the DCC-GARCH model fails to converge in some of the investigated maturities, as the number of parameter to estimate is higher and usually require larger samples with higher number of iterations (see Silvennoinen and Teräsvirta, 2009). Billio and Caporin (2009) argue that a BEKK-GARCH structure is more capable in dealing with a high number of parameter estimations than a DCC-GARCH. Caporin and McAleer (2012) argue that BEKK-GARCH models hold their asymptotic properties under untestable moment conditions, whereas the asymptotic properties of DCC-GARCH models may fail under a set of untestable regularity conditions (like seasonality). As such, BEKK-GARCH models is used in the ensuing analysis.

In Equation (3a), if $c_{j j}$ coefficient is statistically significant, any shock (either positive or negative) to market $j$ will increase the volatility of that market. A statistically significant $d_{j j}$ coefficient indicates that the related market is more reactive to a negative shock than to a positive shock of the same magnitude, resulting in increasing volatility. In contrast, a 
statistically significant $b_{j j}$ coefficient indicates presence of volatility clustering; that is, a high volatile market is followed by a high volatile market in the future, and a low volatile market is followed by a low volatile market.

Equation (3b) tests for volatility spillovers between the markets. If the $b_{i i} b_{j j}$ coefficient is statistically significant $\left(b_{i i}\right.$ and $b_{j j}$ are individually significant) there exists a volatility spillover between either of the markets (see Xiao and Dhesi, 2010; and Zhang et al., 2009). For example, if the $b_{s s} b_{f f}$ coefficient is significant, then there exist significant spillover effects between the time-charter and freight futures markets. Similarly, if the $c_{i i} c_{j j}$ coefficient is statistically significant ( $c_{i i}$ and $c_{j j}$ are individually significant) it indicates that any shock (positive or negative) generated in either one market is transmitted to the other market. For example, if the $c_{s S} c_{f f}$ coefficient is statistically significant, a shock generated in the timecharter market leads to an increase in the volatility of the futures market, and vice versa. Finally, if the $d_{i i} d_{j j}$ coefficient is statistically significant $\left(d_{i i}\right.$ and $d_{j j}$ are individually significant) it indicates that negative shocks generated within either one market affect the volatility of the other market. Similar to the previous example, if the $d_{s s} d_{f f}$ coefficient is significant there exist volatility leverage effects between the time-charter market and the futures market.

\subsection{Price liquidity interaction and liquidity}

This study also investigates the impact of futures trading volume activities on time-charter, freight futures and freight options markets. Referring to Equations (2a), (2b) and (2c) $R_{t-1}$ denotes the lagged ratio of trading volume over open interest, representing the trading activity of the futures market. The lagged value of this ratio is used since trading activities and prices exhibit strong endogenous relationships, and hence, cannot be determined contemporaneously (Lamoureux and Lastrapes, 1994). An increase in the ratio denotes an increase in trading activities at a given amount of open interest, and thus an increase in market liquidity. If the lagged $a_{s}, a_{f}$ or $a_{o}$ coefficient of $R_{t-1}$ is statistically significant and positive (negative) then the corresponding time-charter, freight futures or freight options prices, respectively, will increase (decrease).

To understand the interaction of time-charter, freight futures and options prices, it is important to investigate the liquidity of the derivatives contracts since a liquid market is sensitive to new market information, adjusting prices faster than an illiquid market (Silber, 1991; and Hasbrouck and Seppi, 2001). Alizadeh et al. (2015) use the Amihud liquidity measure in the freight derivatives market to assess the existence of liquidity risk and report that liquidity risk is priced, and thus, liquidity has a significant role to play in FFA returns. However, the Amihud liquidity measure is found to be biased when the sample period includes days where trading volume is thin, while it cannot be defined on the days when the trading volume is zero (see Chelley-Steeley et al. 2015). According to Chelley-Steeley et al. (2015) this occurs because 
the ratio takes the average of absolute returns over the trading volume. Thus, division by zero is not possible, trading days with zero trades are treated as missing values, distorting (inflating) the liquidity ratio. In our sample, there are some days with zero trading activity, and thus, the conventional Amihud (2002) liquidity measure cannot be used (as the denominator cannot be zero). Instead, we employ the Amivest liquidity measure to compare the liquidity of freight futures and options contracts. The Amivest measure was first employed by Cooper et al. (1985), following Amivest Corporation's monthly Liquidity Report published since 1972 (for a detailed explanation, see Foucault et al., 2013). The Amivest ratio reflects the liquidity index of an asset; that is, as the ratio increases the asset is more liquid.

The monthly Amivest measure $\operatorname{Liq}_{k}^{i, j}$ for derivatives contract $i$ ( $i$ takes the value $f$ or $o$ representing freight futures or freight options, respectively) for vessel type $j$ ( $j$ takes the value $c, p$ and $s$ representing Capesize, Panamax or Supramax vessels, respectively) maturing in $k$ periods ahead $(k$ takes the value $+1 \mathrm{M},+2 \mathrm{M},+1 \mathrm{Q},+2 \mathrm{Q},+3 \mathrm{Q},+1 \mathrm{C}$ and $+2 \mathrm{C}$ representing the respective maturity period of the derivatives contracts):

$$
\mathrm{Liq}_{k}^{i, j}=\frac{1}{\eta \mathrm{D}_{t}} \sum_{\mathrm{d}=1}^{\mathrm{D}_{t}} \frac{\mathrm{Vol}_{k, d}^{i, j}}{\left|\mathrm{R}_{k, d}^{i, j}\right|}
$$

where, $\mathrm{D}_{t}$ is the number of trading days in the month $t, \eta$ is the number of contract months for $k$ periods maturities (more specifically, if $k$ takes the value of $+1 \mathrm{M}$ or $+2 \mathrm{M}$, $\eta$ will be one; if $k$ takes the value of $+1 \mathrm{Q}$ or $+2 \mathrm{Q}$ or $+3 \mathrm{Q}$, $\eta$ will be three; if $k$ takes the value of $+1 \mathrm{C}$ or $+2 \mathrm{C}$, $\eta$ will be twelve), $\mathrm{R}_{k, d}^{i, j}$ and $\mathrm{Vol}_{k, d}^{i, j}$ represent the daily returns and trading volume, respectively, for derivatives contract $i$, for vessel type $j$, maturing in period $k$, on day $d$ (within month $t$ ). The average $\operatorname{Liq}_{k}^{i, j}$ is estimated for Capesize, Panamax and Supramax vessels at different contract maturities to assess the liquidity level of the freight futures and options contracts under investigation; that is, derivatives contracts with higher average value of $\mathrm{Liq}_{k}^{i, j}$ have higher market liquidity.

\section{Empirical Research Results}

\subsection{Descriptive statistics, stationarity and cointegration}

Table 1 presents preliminary descriptive statistics for Capesize logarithmic returns of sixmonth time-charter rates, as well as corresponding freight futures and freight options prices for different contract maturities. ${ }^{16}$ Untabulated descriptive data statistics show that Capesize timecharter rates are more volatile than those for Panamax vessels, followed by Supramax vessels. This is consistent with the view that the larger the vessel the less flexible it is in terms of

\footnotetext{
${ }^{16}$ For the brevity of space only the empirical results for Capesize vessels are presented in this study, but results for Panamax and Supramax vessels are available upon request.
} 
carrying a wider range of cargoes, trading in more routes and being able to approach more ports and terminals. Hence, when oversupply of vessels and/or lack of sufficient cargos in the market lead to low freight rates, Capesize vessels are affected the most due to their low flexibility, inducing significant volatility in rates (see Kavussanos, 1996). Moreover, Capesize futures and options prices are more volatile than for Panamax vessels, followed by Supramax vessels. In Table 1 it can be seen that the standard deviation of near-month maturity freight futures and options contracts is the highest before it starts to decrease as the distance to maturities increases, which is in line with the literature (Miller, 1979; and Milonas, 1986).

Table 2 reports unit root tests for Capesize time-charter rates, corresponding freight futures and options, as well as the trading volume-to-open interest ratio for different freight futures maturities and vessel types. Conventional ADF (1981) and PP (1988) tests applied on loglevels and log-first differences prices reveal that all prices are stationary in log-first difference and have unit root in log-levels. The only exception is for near-maturity freight options for all three vessel-types and the trading ratio, since they are all stationary in log-levels (results for Panamax and Supramax vessels are not tabulated, but available upon request). The KPSS (1992) test results are also in line with the above ADP and PP unit root results. Furthermore, unit root tests with one structural break (Perron and Vogelsang, 1992) offer similar results to those without a structural break. One-month forward freight options (as well as the liquidity trading ratio variables) are found stationary in levels with and without a structural break, except for Supramax options.

Johansen (1988) cointegration tests, reported in Table 3, show that freight futures and options contracts exhibit cointegration with time-charter rates for Capesize vessels near-calendar year and second-calendar year. In unreported results for Panamax and Supramax vessels, second near-month and near-quarter freight futures and options contracts exhibit long-run relationships with their corresponding time-charter rates. The Schwartz Bayesian Information Criterion (SBIC), used to determine the lag length of the VAR models, indicates different lag length specifications for different maturities. The Johansen et al. (2000) test reveals that in the presence of one structural break, several more cointegrating relationships between time-charter rates, freight futures and freight options exist; In particular, time-charter rates with: (i) second near-month maturity Capesize futures and options (for example, see price series T/C - F_C2 O_C2 in Table 3); (ii) second near-month, near-quarter, second near-quarter, third near-quarter, near calendar year, and second near-calendar year maturity Panamax futures and options (not tabulated); and (iii) for all seven maturity Supramax futures and options (not tabulated). For Capesize and Panamax vessels, the structural break point is located between September 2014 and February 2015 during which the associated sizes of orderbooks (number of newbuilding vessels ordered at shipyards under construction and delivery) increased significantly, pushing 
the futures prices at much lower levels than the time-charter rates. ${ }^{17}$ The break point for Supramax vessels is observed during January 2015, which coincide with a significant drop in crude oil prices, resulting in increased tanker freight rates, and as a result, to a significant number of conversions of dry-bulk vessels under construction to tankers.

Table 1 - Descriptive Statistics of Daily Capesize Six-month Time-charter (T/C), Futures (F) and Options (O) Log-prices

\begin{tabular}{|c|c|c|c|c|c|c|c|c|c|}
\hline & $T$ & Mean & Std & Skew & Kurt & J-B & $\mathbf{Q ( 1 2 )}$ & Q2(12) & $\overline{\mathrm{ARCH}(5)}$ \\
\hline T/C & 849 & 0.000031 & 0.00828 & 1.177 & 11.760 & $\begin{array}{l}73.030 \\
{[0.001]}\end{array}$ & $\begin{array}{c}580.988 \\
{[0.000]}\end{array}$ & $\begin{array}{c}317.530 \\
{[0.000]}\end{array}$ & $\begin{array}{l}192.418 \\
{[0.000]}\end{array}$ \\
\hline F_M1 & 849 & 0.000022 & 0.00954 & 0.375 & 10.164 & $\begin{array}{l}26.555 \\
{[0.001]}\end{array}$ & $\begin{array}{c}25.609 \\
{[0.0122]}\end{array}$ & $\begin{array}{l}21.848 \\
{[0.039]}\end{array}$ & $\begin{array}{l}11.861 \\
{[0.037]}\end{array}$ \\
\hline O_M1 & 849 & 0.000087 & 0.02161 & 3.390 & 18.604 & $\begin{array}{c}66.512 \\
{[0.001]}\end{array}$ & $\begin{array}{c}15.093 \\
{[0.236]}\end{array}$ & $\begin{array}{c}5.733 \\
{[0.929]}\end{array}$ & $\begin{array}{c}2.372 \\
{[0.796]}\end{array}$ \\
\hline F_M2 & 849 & 0.000024 & 0.00716 & -0.116 & 13.240 & $\begin{array}{l}19.724 \\
{[0.001]}\end{array}$ & $\begin{array}{l}20.498 \\
{[0.058]}\end{array}$ & $\begin{array}{c}2.339 \\
{[0.999]}\end{array}$ & $\begin{array}{c}1.585 \\
{[0.903]}\end{array}$ \\
\hline O_M2 & 849 & 0.000086 & 0.01102 & 2.051 & 12.779 & $\begin{array}{l}38.382 \\
{[0.001]}\end{array}$ & $\begin{array}{c}9.506 \\
{[0.659]}\end{array}$ & $\begin{array}{c}6.595 \\
{[0.883]}\end{array}$ & $\begin{array}{c}4.763 \\
{[0.445]}\end{array}$ \\
\hline F_Q1 & 849 & 0.000000 & 0.00733 & -1.010 & 59.944 & $\begin{array}{l}16.778 \\
{[0.002]}\end{array}$ & $\begin{array}{c}9.857 \\
{[0.629]}\end{array}$ & $\begin{array}{c}0.294 \\
{[0.100]}\end{array}$ & $\begin{array}{c}0.145 \\
{[1.000]}\end{array}$ \\
\hline O_Q1 & 849 & 0.000027 & 0.01099 & 5.310 & 52.960 & $\begin{array}{l}39.382 \\
{[0.001]}\end{array}$ & $\begin{array}{c}8.659 \\
{[0.732]}\end{array}$ & $\begin{array}{c}0.514 \\
{[1.000]}\end{array}$ & $\begin{array}{c}0.352 \\
{[1.000]}\end{array}$ \\
\hline F_Q2 & 849 & -0.000165 & 0.00585 & -5.949 & 97.043 & $\begin{array}{c}4.879 \\
{[0.081]}\end{array}$ & $\begin{array}{c}4.308 \\
{[0.977]}\end{array}$ & $\begin{array}{c}0.363 \\
{[1.000]}\end{array}$ & $\begin{array}{c}0.144 \\
{[1.000]}\end{array}$ \\
\hline O_Q2 & 849 & -0.000179 & 0.00766 & -4.590 & 77.674 & $\begin{array}{c}5.536 \\
{[0.059]}\end{array}$ & $\begin{array}{c}6.512 \\
{[0.888]}\end{array}$ & $\begin{array}{c}2.406 \\
{[1.000]}\end{array}$ & $\begin{array}{c}2.110 \\
{[0.834]}\end{array}$ \\
\hline F_Q3 & 849 & -0.000062 & 0.00584 & -2.870 & 81.256 & $\begin{array}{c}3.844 \\
{[0.134]}\end{array}$ & $\begin{array}{c}11.564 \\
{[0.481]}\end{array}$ & $\begin{array}{c}0.405 \\
{[1.000]}\end{array}$ & $\begin{array}{c}0.222 \\
{[1.000]}\end{array}$ \\
\hline O_Q3 & 849 & -0.000066 & 0.00821 & -3.296 & 67.435 & $\begin{array}{c}8.094 \\
{[0.021]}\end{array}$ & $\begin{array}{c}8.481 \\
{[0.747]}\end{array}$ & $\begin{array}{c}0.873 \\
{[1.000]}\end{array}$ & $\begin{array}{c}0.550 \\
{[0.990]}\end{array}$ \\
\hline F_C1 & 849 & -0.000076 & 0.00239 & 1.601 & 22.310 & $\begin{array}{l}48.480 \\
{[0.001]}\end{array}$ & $\begin{array}{l}33.746 \\
{[0.001]}\end{array}$ & $\begin{array}{c}2.471 \\
{[0.998]}\end{array}$ & $\begin{array}{c}1.856 \\
{[0.869]}\end{array}$ \\
\hline O_C1 & 849 & -0.000104 & 0.00697 & 1.041 & 54.603 & $\begin{array}{l}51.557 \\
{[0.001]}\end{array}$ & $\begin{array}{l}111.391 \\
{[0.000]}\end{array}$ & $\begin{array}{l}213.733 \\
{[0.000]}\end{array}$ & $\begin{array}{c}282.188 \\
{[0.000]}\end{array}$ \\
\hline F_C2 & 849 & -0.000069 & 0.00170 & 2.323 & 35.343 & $\begin{array}{l}55.012 \\
{[0.001]}\end{array}$ & $\begin{array}{l}28.541 \\
{[0.005]}\end{array}$ & $\begin{array}{c}2.392 \\
{[0.999]}\end{array}$ & $\begin{array}{c}1.959 \\
{[0.855]}\end{array}$ \\
\hline O_C2 & 849 & -0.000145 & 0.00809 & -0.047 & 69.256 & $\begin{array}{l}124.127 \\
{[0.001]}\end{array}$ & $\begin{array}{l}141.883 \\
{[0.000]}\end{array}$ & $\begin{array}{c}209.641 \\
{[0.000]}\end{array}$ & $\begin{array}{c}330.775 \\
{[0.000]}\end{array}$ \\
\hline
\end{tabular}

Notes: Data series are daily prices measured in logarithmic first-difference. $T$ is the number of observations. Squared brackets [.] are significance levels. T/C is BFA time-charter average basket; F_M1 is near-month freight futures; $\mathrm{O} \_\mathrm{M} 1$ is near-month at-the-money freight options; F_M2 is second near-month freight futures; $\mathrm{O} \_\mathrm{M} 2$ is second near-month at-the-money freight options; F_Q1 is near-quarter freight futures; O_Q1 is near-quarter atthe-money freight options; $F_{-} Q 2$ is second near-quarter freight futures; $\mathrm{O}_{-} \mathrm{Q} 2$ is second near-quarter at-the-money freight options; F_Q3 is third near-quarter freight futures; $\mathrm{O}_{-} \mathrm{Q} 3$ is third near-quarter at-the-money freight options; F_C1 is near-calendar freight futures; $\mathrm{O}_{-} \mathrm{C} 1$ is near-calendar at-the-money freight options; F_C2 is second nearcalendar freight futures; O_C2 is second near-calendar at-the-money freight options. Mean is the sample mean of the series. Std is the estimated standard deviation of the series. Skew and Kurt are the estimated centralized third (skewness) and fourth (kurtosis) moments of the data, respectively. J-B is the Jarque and Bera (1980) test for normality. Q(12) and Q2(12) is the Ljung and Box (1978) Q-statistic on the first 12-lags of the sample autocorrelation function of the raw price series and of the squared price series, respectively; the statistic is distributed as $\chi^{2}(12)$. ARCH(5) is the Engle (1982) test for ARCH effects; the statistic is distributed as $\chi^{2}(5)$. Results for Panamax and Supramax markets are provided upon request.

Table 2 - Unit Root Tests of Capesize Time-charter, Futures and Options log-prices at

\footnotetext{
${ }^{17}$ Typically, during a low market, such the one since 2009, market participants anticipate the market to recover, and hence, futures prices are usually higher than the underlying time-charter rates (contango market), except during mid-2014 to beginning of 2015 for Capesize and Panamax vessels.
} 
Different Maturities (04/04/2013 - 31/08/2016)

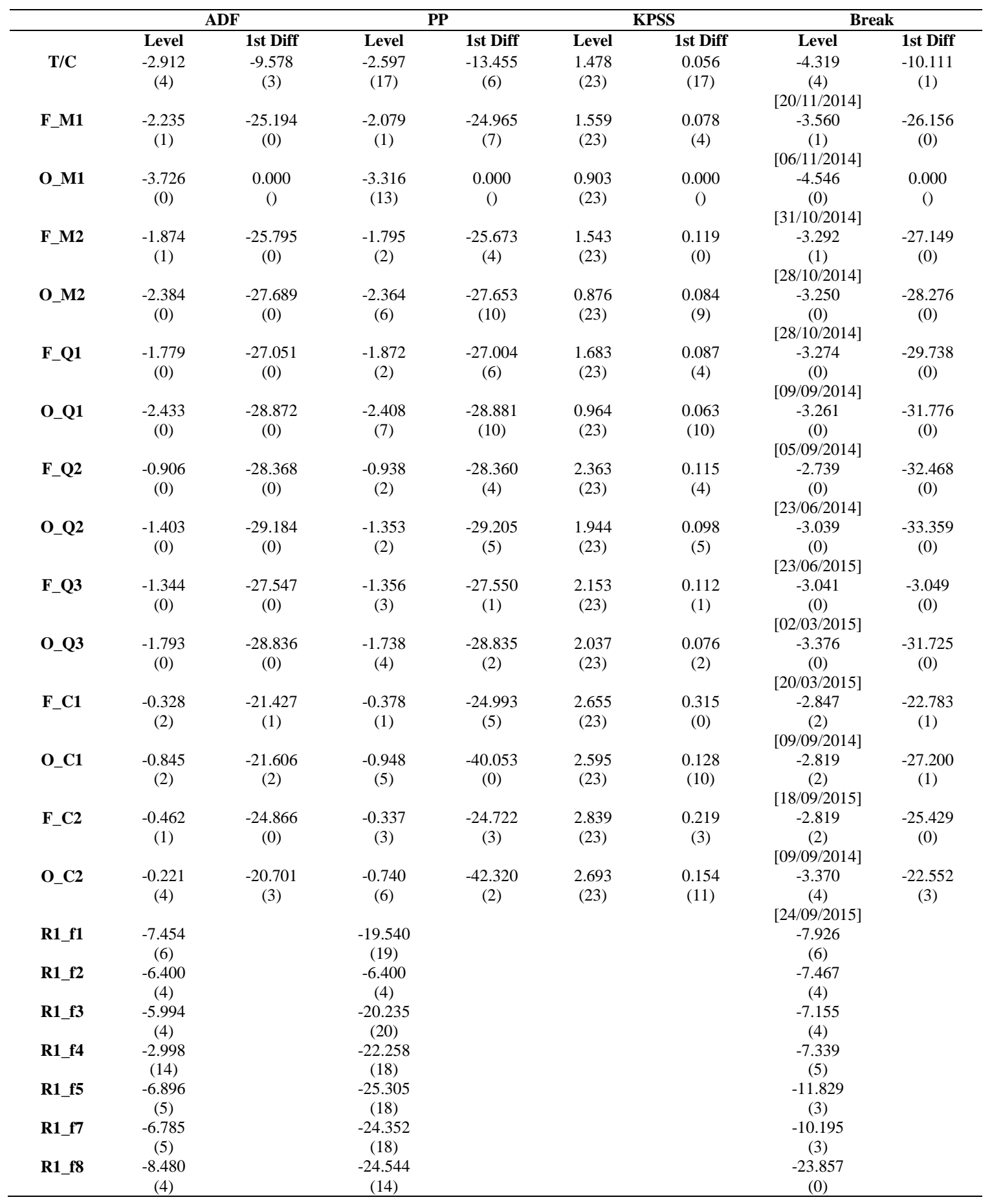

Notes: See Table 1 for a notation of the variables. Parentheses (.) are number of lags, while squared brackets [.] are the breakpoint dates. R_M1 is the ratio of daily trading volume over open interest for near-month futures contracts; R_M2 is the ratio for second near-month futures contracts; R_Q1 is the ratio for nearquarter futures contracts; R_Q2 is the ratio for second near-quarter futures contracts; R_Q3 is the ratio for third near-quarter futures contracts; R_C1 is the ratio for near-calendar futures contracts; and R_C2 is the ratio for second near-calendar futures contracts; Results for Panamax and Supramax markets are not tabulated but can be provided upon request. 
Table 3 - Cointegration Tests for Capesize Vessels

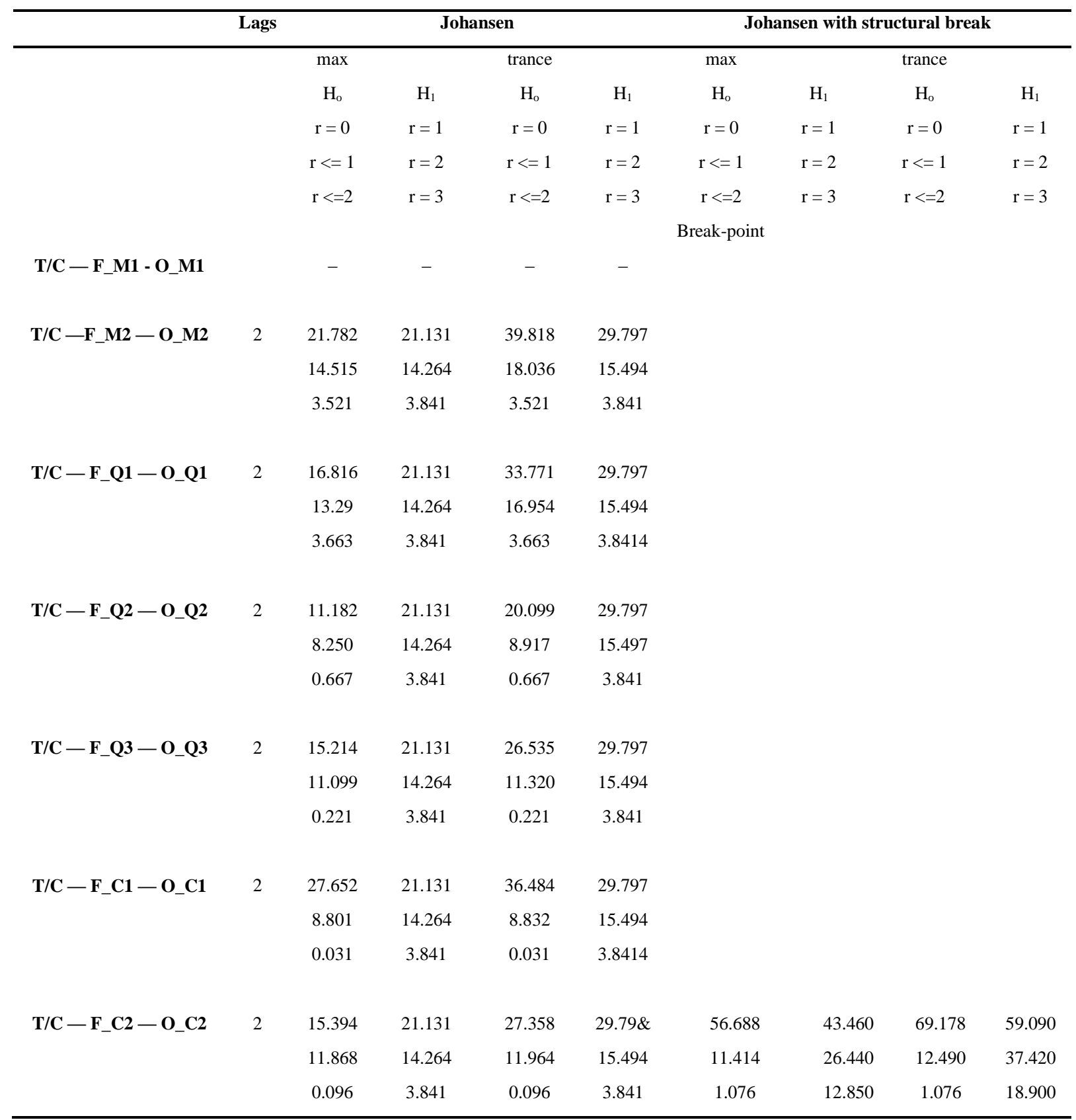

Notes: Lags is the lag length of the Vector Autoregressive (VAR) models used for the cointegration test without a structural break (Johansen, 1988), and for the cointegration test with a structural break on the constant and slope (Johansen et al., 2000). The lag length is determined by minimizing the SBIC (1978). $r$ represents the number of cointegrating vectors. $\lambda_{\mathrm{i}}$, is the $\lambda \max$ and $\lambda$ trace cointegration tests of the estimated eigenvalues of the $\Pi$ matrix in Equation (1). Critical values for the $\lambda \max$ and $\lambda$ trace statistics for cointegration without a structural break and for cointegration with a structural break are calculated and provided under alternate hypothesis. Results for Panamax and Supramax markets are not tabulated, but can be provided upon request.

Overall, distant-maturity contracts, for all three types of vessels exhibit cointegrating relationships with their corresponding time-charter rates. The coefficient of the error-correction terms are significant and negative, indicating that the documented cointegrating relationship among the investigated markets acts as a buffer to any external shocks keeping them together 
in a long-run equilibrium relationship. ${ }^{18}$ This may be the result of the supply of newbuilding vessels matching cargo requirements, as shipyards typically take some time to deliver a vessel. ${ }^{19}$ As the size of the orderbook helps in anticipating freight rates, the time period between the order and delivery of newbuilding vessels is matched by the distant-maturity derivatives contracts. Furthermore, near-maturity derivatives contracts also appear to exhibit long-run relationships with time-charter rates for all three types of vessels, with the error-correction terms being significant and negative, similar to the case of distant-maturity contracts. ${ }^{20}$ This may be due to the liquidity of the freight futures contracts, as it is significantly higher for nearmaturity contracts (explained in the later part of the study), resulting in a strong adjustment of near-maturity derivatives prices to the time-charter prices.

\subsection{Spillover effect on returns and volatilities}

Tables $4 \mathrm{a}$ and $4 \mathrm{~b}$ present the spillover effects results of returns and volatilities between timecharter rates and corresponding freight futures and options prices, for the three major dry-bulk vessels under different contract maturities. VECM models are used when cointegration is detected and VAR models when it is not. Panel A presents the interaction between the returns of the underlying time-charter market and the two derivatives markets, along with the trading activity of futures markets. In the system of equations, some variables are found to be weakly statistically significant jointly, although individually fail to explain the dependent variable. Wald tests are conducted to understand whether individual markets (say the freight options market) are sufficient to explain the dependent market (say physical time-charter market) or just have an explanatory power only in presence of stronger markets (say freight futures markets). Panel B shows the interactions of volatilities between the time-charter rates, freight futures and options prices. The empirical findings are as follows.

\subsubsection{Spillover effects under cointegrating relationships}

Table 4a presents sixteen models where cointegrating relationships are found between timecharter rates, freight futures and freight options prices for different vessel. These are: (i) nearby maturity contracts (near-month Supramax (S_M1), second near-month Capesize (C_M2), Panamax (P_M2) and Supramax (S_M2)); (ii) medium maturity contracts (near-quarter and second near-quarter Panamax (P_Q1 and P_Q2) and Supramax (S_Q1 and S_Q2) and third near-quarter Supramax (S_Q3); and (iii) distant-maturities contracts (near-calendar and second near-calendar Capesize (C_C1 and C_C2) and Panamax (P_C1 and P_C2), and Supramax (S_C1 and S_C2)). In Panel A, the lagged error-correction terms ect1 and ect2 (ect2

\footnotetext{
${ }^{18}$ Near-calendar and second near-calendar contracts for Capesize (C_C1 and C_C2), Panamax (P_C1 and P_C2) and Supramax (S_C1 and S_C2) vessels.

${ }^{19}$ Delivery time and availability of slots vary from one shipyard to another. If there is relatively no waiting time delivery typically takes from 12 to 24 months.

${ }^{20}$ Second near-month and near-quarter contracts for Panamax (P_M2 and P_Q1), from near-month to near-quarter contracts for Supramax (S_M1, S_M2 and S_Q1), and second near-month contracts for Capesize (C_M2), except near-quarter contracts for Capesize (C_Q1).
} 
is presented only in the case where two cointegrating vectors are established) are significant in all cases with at least one cointegrating vector in the regression model being significant. Most of the ect coefficients (speed of adjustment) are negative, indicating that variables that divert from the cointegrating relationship increase in value to restore the long-run equilibrium relationship.

Firstly, according to the short-run dynamics of the models, lagged time-charter rates significantly explain most of the futures prices (apart from the second near-quarter (S_Q2) Supramax regression), while all lagged futures prices significantly explain time-charter rates, apart from one regression (near-quarter (S_Q1) Supramax). This indicates that there is a bidirectional spillover effect in returns between the time-charter market and the futures market, but according to a Wald (joint significance) test this effect runs stronger from the futures (derivatives) market towards the time-charter (underlying) freight market.

Secondly, in terms of the interaction between freight futures and freight options returns, lagged options prices significantly explain futures prices only in eight out of sixteen models (second near-month (P_M2) and second near-quarter (P_Q2) Panamax, and near-month (S_M1), second near-month (S_M2), second near-quarter (S_Q2), third near-quarter (S_Q3), nearcalendar (S_C1) and second near-calendar (S_C2) Supramax), while lagged futures prices significantly explain freight options prices in all sixteen models. In addition, the joint impact (according to a Wald test) of freight futures returns on freight options returns is stronger than the reverse, indicating that the freight futures market is informationally leading the freight options market.

Thirdly, results on the interaction between lagged time-charter rates and lagged freight options prices indicate that time-charter returns significantly explain freight options returns for all models apart from four regressions (second near-month (P_M2) Panamax, and near-month (S_M1) near-quarter (S_Q1) and second near-calendar (S_C2) Supramax). In contrast, lagged freight options returns can explain time-charter rates only in seven (out of sixteen) models (near-calendar (C_C1) Capesize, near-quarter (P_Q1), second near-quarter (P_Q2), third nearquarter $\left(\mathrm{P}_{-} \mathrm{Q} 3\right)$, near-calendar $\left(\mathrm{P}_{-} \mathrm{C} 1\right)$ and second near-calendar $\left(\mathrm{P} \_\mathrm{C} 2\right)$ Panamax and nearquarter (S_Q1) Supramax). This rather unexpected result indicates that the time-charter (underlying) market is informationally leading freight options (derivatives) market, which is inconsistent with conventional wisdom and expectations. Overall, results from Wald joint tests suggest that information in returns is transmitted first from the freight futures market to the time-charter market, and then is spilled over to the freight options market.

Panel B of Table 4a presents the parameter estimates of the conditional variance models. The $b_{j j}$ coefficient is significant in all regressions indicating a strong volatility spillover between time-charter rates and the corresponding freight futures and freight options prices for all three vessel types. Also, the $c_{j j}$ coefficient is significant in all models (except for near-month (S_M1) Supramax), indicating that a shock (either positive or negative) can be transmitted, say, from 
the futures market to the time-charter or options market, leading to an increase in the latter market's volatility. Furthermore, the leverage effect $d_{j j}$ coefficient for time-charter rates is statistically significant in eleven (out of sixteen) models (apart from near calendar (C_C1) Capesize, second near-quarter (P_Q2) Panamax, second near-month (S_M2), near-quarter (S_Q1) and second near-calendar (S_C2) Supramax), indicating that a negative shock generated in the time-charter market does not necessarily result in increasing volatilities in other markets, as compared to a positive shock of the same magnitude. In contrast, the leverage volatility effect is more prevalent in the derivatives markets, as it is observed in all sixteen models. This could be a result of the increased flexibility of derivatives contracts over physical trades, as discussed earlier. Accordingly, open positions in freight derivatives markets can be closed almost immediately upon the arrival of bad news, resulting in an increase in market volatility.

\subsubsection{Spillover effects under non-cointegrating relationships}

Table $4 \mathrm{~b}$ presents five models where cointegrating relationships (with or without structural breaks) are not found between time-charter rates, freight futures and options prices for different vessel types. These are: (i) nearby maturity contracts (near-month Capesize (C_M1) and Panamax (P_M1)); and (ii) medium maturity contracts (near-quarter (C_Q1), second nearquarter C_Q2) and third near-quarter (C_Q3) Capesize).

In Panel A, the coefficients of the lagged returns indicate the presence of significant short-run relationships between time-charter rates, freight futures and options prices. Firstly, lagged freight futures prices significantly explain time-charter rates in four (out of five) models (C_M1, C_Q1, C_Q3 and P_M1), and also four models (C_Q1, C_Q2, C_Q3 and P_M1) the lagged time-charter rates can significantly explain futures prices. These results indicate a bidirectional spillover effect between the freight futures and the time-charter markets, but with a stronger information flow from the futures (derivatives) market to the time-charter (underlying) market considering Wald test, which is in accordance to the theory and expectations.

Secondly, results on the interactions between freight futures and freight options prices indicate that freight futures returns significantly explain options returns in four (out of five) models (C_M1, C_Q1, C_Q3 and P_M1), while freight options returns can explain futures returns in four models (C_M1, C_Q1, C_Q3 and P_M1). Also, based on the magnitude of the joint significance of the lagged variables (Wald test), the results point to stronger spillover effects from the freight futures market to the freight options market.

Thirdly, it can be seen that time-charter rates are able to significantly explain freight options returns in all five models (C_M1, C_Q1, C_Q2, C_Q3 and P_M1), while options returns can explain time-charter rates in only three cases (C_M1, C_Q3 and P_M1). These results confirm the presence of a bi-directional flow of information between time-charter returns and freight options returns. Wald joint tests indicate that new market information is first reflected in the 
futures market, before it is spilled in time-charter market, and finally appearing in the options market.

Panel B of Table $4 \mathrm{~b}$ presents the parameter estimates of the conditional variance models. It is observed that the $b_{j j}$ coefficient is significant in all models, indicating an existence of volatility spillovers between time-charter, freight futures and options markets. The $c_{j j}$ coefficient is statistically significant in all models (except in C_Q2 and C_Q3), indicating that a shock (either positive or negative) can be transmitted between the three markets, similarly to the results in the previous section for the cointegrating models. Finally, the leverage volatility effect, according to the $d_{j j}$ coefficient, is observed in four models for the derivatives markets (C_M1, C_Q1, C_Q2 and P_M1), but only in three models for the time-charter market (C_M1, C_Q1 and P_M1). 
Table 4a. Maximum-likelihood Estimates of Restricted BEKK VECM-GARCH Models

\begin{tabular}{|c|c|c|c|c|c|c|c|c|}
\hline & C_M2 & C_C1 & C_C2 & P_M2 & P_Q1 & P_Q2 & P_Q3 & P_C1 \\
\hline & $(\mathrm{T} / \mathrm{C})$ & $(\mathrm{T} / \mathrm{C})$ & $(\mathrm{T} / \mathrm{C})$ & $(\mathrm{T} / \mathrm{C})$ & $(\mathrm{T} / \mathrm{C})$ & $(\mathrm{T} / \mathrm{C})$ & $(\mathrm{T} / \mathrm{C})$ & $(\mathrm{T} / \mathrm{C})$ \\
\hline & (Futures) & (Futures) & (Futures) & (Futures) & (Futures) & (Futures) & (Futures) & (Futures) \\
\hline & (Options) & (Options) & (Options) & (Options) & (Options) & (Options) & (Options) & (Options) \\
\hline \multicolumn{9}{|c|}{ Panel A: Conditional mean parameters } \\
\hline \multirow[t]{3}{*}{ ect1 } & $-0.022^{\mathrm{a}}$ & $-0.005^{b}$ & $-0.004^{\mathrm{a}}$ & -0.0003 & $-0.001^{b}$ & $-0.004^{\mathrm{a}}$ & $-0.003^{\mathrm{a}}$ & $-0.003^{\mathrm{a}}$ \\
\hline & $-0.017^{\mathrm{a}}$ & $0.004^{\mathrm{a}}$ & 0.000 & 0.000 & -0.002 & $-0.006^{a}$ & $0.008^{a}$ & 0.001 \\
\hline & $-0.019^{a}$ & $0.010^{\mathrm{a}}$ & $0.001^{\mathrm{a}}$ & $-0.020^{a}$ & $-0.012^{\mathrm{a}}$ & $-0.019^{a}$ & 0.002 & 0.000 \\
\hline \multirow[t]{3}{*}{ ect2 } & $0.031^{\mathrm{a}}$ & - & - & - & - & - & - & -0.002 \\
\hline & $0.036^{\mathrm{a}}$ & - & - & - & - & - & - & $-0.038^{\mathrm{a}}$ \\
\hline & $0.078^{a}$ & - & - & - & - & - & - & $0.032^{\mathrm{a}}$ \\
\hline \multirow[t]{3}{*}{ T/C (lag 1) } & $0.555^{\mathrm{a}}$ & $0.551^{\mathrm{a}}$ & $0.602^{a}$ & $0.871^{\mathrm{a}}$ & $0.872^{\mathrm{a}}$ & $1.012^{\mathrm{a}}$ & $1.104^{\mathrm{a}}$ & $1.008^{\mathrm{a}}$ \\
\hline & $-0.095^{a}$ & $-0.121^{a}$ & $-0.044^{a}$ & $0.081^{\mathrm{a}}$ & $0.070^{c}$ & $0.269^{a}$ & $0.173^{\mathrm{a}}$ & $0.103^{b}$ \\
\hline & $-0.098^{a}$ & $-0.180^{a}$ & $-0.035^{a}$ & 0.039 & $-0.101^{a}$ & $0.278^{a}$ & $0.192^{\mathrm{a}}$ & $0.136^{c}$ \\
\hline \multirow[t]{3}{*}{ Futures (lag 1) } & $0.311^{\mathrm{a}}$ & $0.808^{a}$ & $1.164^{\mathrm{a}}$ & $0.074^{\mathrm{a}}$ & $0.037^{\mathrm{a}}$ & -0.004 & -0.008 & $0.129^{a}$ \\
\hline & $0.205^{b}$ & $0.278^{a}$ & $0.393^{\mathrm{a}}$ & $0.386^{\mathrm{a}}$ & $0.215^{\mathrm{a}}$ & $-0.227^{\mathrm{a}}$ & $0.207^{\mathrm{a}}$ & $0.303^{\mathrm{a}}$ \\
\hline & $0.290^{\mathrm{a}}$ & $0.451^{\mathrm{a}}$ & $0.650^{\mathrm{a}}$ & $0.522^{\mathrm{a}}$ & $0.091^{\mathrm{b}}$ & $-0.281^{\mathrm{a}}$ & $0.302^{\mathrm{a}}$ & $0.379^{\mathrm{a}}$ \\
\hline \multirow[t]{3}{*}{ Options (lag 1) } & -0.036 & $0.104^{\mathrm{a}}$ & 0.040 & -0.0001 & $0.018^{a}$ & $0.036^{\mathrm{a}}$ & $0.052^{\mathrm{a}}$ & $0.018^{b}$ \\
\hline & -0.072 & -0.021 & 0.004 & $-0.094^{\mathrm{a}}$ & -0.031 & $0.055^{\mathrm{a}}$ & 0.014 & -0.019 \\
\hline & $-0.135^{c}$ & -0.078 & $-0.120^{\mathrm{a}}$ & $-0.172^{a}$ & $0.057^{c}$ & 0.011 & $0.093^{\mathrm{a}}$ & -0.049 \\
\hline \multirow[t]{3}{*}{ T/C (lag 2) } & - & - & - & - & - & $-0.167^{a}$ & $-0.239^{a}$ & $-0.175^{a}$ \\
\hline & - & - & - & - & - & $-0.519^{a}$ & $-0.234^{\mathrm{a}}$ & $-0.193^{\mathrm{a}}$ \\
\hline & - & - & - & - & - & $-0.574^{\mathrm{a}}$ & $-0.193^{a}$ & $-0.229^{a}$ \\
\hline \multirow[t]{3}{*}{ Futures (lag 2) } & - & - & - & - & - & 0.020 & 0.012 & 0.012 \\
\hline & - & - & - & - & - & $-0.192^{a}$ & $0.069^{b}$ & $-0.132^{\mathrm{a}}$ \\
\hline & - & - & - & - & - & $-0.135^{\mathrm{a}}$ & $0.096^{\mathrm{a}}$ & $-0.382^{a}$ \\
\hline \multirow[t]{3}{*}{ Options (lag 2) } & - & - & - & - & - & 0.006 & 0.013 & 0.005 \\
\hline & - & - & - & - & - & 0.002 & -0.025 & -0.008 \\
\hline & - & - & - & - & - & $-0.091^{\mathrm{c}}$ & -0.015 & $0.241^{\mathrm{a}}$ \\
\hline \multirow[t]{3}{*}{ Ratio (lag 1) } & $0.004^{\mathrm{a}}$ & 0.001 & 0.0007 & 0.0002 & 0.0002 & 0.000 & -0.0001 & 0.0004 \\
\hline & $0.003^{\mathrm{a}}$ & -0.0001 & $0.0005^{c}$ & -0.0006 & $0.001^{\mathrm{c}}$ & 0.000 & $-0.001^{\mathrm{a}}$ & 0.0001 \\
\hline & $0.006^{\mathrm{a}}$ & 0.0004 & $0.0009^{a}$ & 0.000 & $0.001^{\mathrm{a}}$ & $0.003^{\mathrm{a}}$ & -0.0003 & 0.0002 \\
\hline \multicolumn{9}{|l|}{ Wald Test } \\
\hline Futures $\rightarrow T / C$ & $34.95^{\mathrm{a}}$ & $95.61^{\mathrm{a}}$ & $85.02^{\mathrm{a}}$ & $49.39^{\mathrm{a}}$ & $31.66^{\mathrm{a}}$ & 0.90 & 0.64 & $29.80^{\mathrm{a}}$ \\
\hline Options $\rightarrow \mathrm{T} / \mathrm{C}$ & 0.76 & $3.97^{\mathrm{b}}$ & 2.11 & 0.04 & $15.94^{\mathrm{a}}$ & $9.29^{\mathrm{b}}$ & $16.72^{\mathrm{a}}$ & $10.82^{\mathrm{a}}$ \\
\hline Joint $\rightarrow \mathrm{T} / \mathrm{C}$ & $101.53^{\mathrm{a}}$ & $120.37^{\mathrm{a}}$ & $98.41^{\mathrm{a}}$ & $101.06^{\mathrm{a}}$ & $100.14^{\mathrm{a}}$ & $30.49^{\mathrm{a}}$ & $51.23^{\mathrm{a}}$ & $59.94^{\mathrm{a}}$ \\
\hline $\mathrm{T} / \mathrm{C} \rightarrow$ Futures & $9.33^{\mathrm{a}}$ & $24.67^{\mathrm{a}}$ & $12.71^{\mathrm{a}}$ & 0.64 & 0.23 & $14.11^{\mathrm{a}}$ & $10.37^{\mathrm{a}}$ & $10.59^{\mathrm{a}}$ \\
\hline Options $\rightarrow$ Futures & 1.59 & 0.25 & 0.2 & 0.94 & 0.37 & 0.65 & 0.33 & 2.68 \\
\hline Joint $\rightarrow$ Futures & $10.57^{\mathrm{a}}$ & $24.84^{\mathrm{a}}$ & $12.93^{\mathrm{a}}$ & 1.43 & 0.61 & $15.04^{\mathrm{a}}$ & $10.5^{b}$ & $13.14^{\mathrm{b}}$ \\
\hline $\mathrm{T} / \mathrm{C} \rightarrow$ Options & $8.64^{\mathrm{a}}$ & $11.79^{\mathrm{a}}$ & $3.76^{\mathrm{b}}$ & $3.15^{\mathrm{c}}$ & 0.37 & $7.31^{\mathrm{a}}$ & 3.69 & 0.02 \\
\hline Futures $\rightarrow$ Options & $10.84^{\mathrm{a}}$ & $112.07^{\mathrm{a}}$ & $28.27^{\mathrm{a}}$ & $9.86^{\mathrm{a}}$ & $18.74^{\mathrm{a}}$ & $20.03^{\mathrm{a}}$ & $43.54^{\mathrm{a}}$ & $101.73^{\mathrm{a}}$ \\
\hline Joint $\rightarrow$ Options & $16.65^{\mathrm{a}}$ & $113.78^{\mathrm{a}}$ & $28.99^{\mathrm{a}}$ & $11^{\mathrm{a}}$ & $18.74^{\mathrm{a}}$ & $31.83^{\mathrm{a}}$ & $54.76^{\mathrm{a}}$ & $116.48^{\mathrm{a}}$ \\
\hline \multicolumn{9}{|c|}{ Panel B: Conditional variance parameters } \\
\hline \multirow[t]{3}{*}{$a_{\mathrm{jj}}$} & $6.33 e-05^{a}$ & $0.000277^{\mathrm{a}}$ & $0.000208^{a}$ & $1.8 \mathrm{e}-05^{\mathrm{a}}$ & $3.2 \mathrm{e}-05^{\mathrm{a}}$ & $4.44 \mathrm{e}-05^{\mathrm{a}}$ & $2.24 \mathrm{e}-05^{\mathrm{a}}$ & $4.81 \mathrm{e}-05^{\mathrm{a}}$ \\
\hline & $2.33 \mathrm{e}-05^{\mathrm{a}}$ & 3.02E-07 & $8.17 \mathrm{e}-06^{\mathrm{a}}$ & $2.2 \mathrm{e}-05^{\mathrm{a}}$ & $0.000208^{\mathrm{a}}$ & $9.95 \mathrm{e}-06^{\mathrm{a}}$ & $0.000196^{\mathrm{a}}$ & $3.77 \mathrm{e}-06^{\mathrm{a}}$ \\
\hline & $-2.88 \mathrm{e}-05^{\mathrm{a}}$ & $-7.34 \mathrm{e}-06^{\mathrm{a}}$ & $3.54 \mathrm{E}-07$ & $-2.23 \mathrm{E}-05$ & $0.000466^{\mathrm{a}}$ & $1.91 \mathrm{e}-05^{\mathrm{a}}$ & $0.000282^{\mathrm{a}}$ & $7.97 \mathrm{e}-06^{\mathrm{a}}$ \\
\hline \multirow[t]{3}{*}{$c_{\mathrm{jj}}$} & $0.202^{\mathrm{a}}$ & $0.455^{\mathrm{a}}$ & $0.324^{\mathrm{a}}$ & $0.631^{\mathrm{a}}$ & $0.549^{\mathrm{a}}$ & $0.666^{\mathrm{a}}$ & $0.479^{a}$ & $0.681^{\mathrm{a}}$ \\
\hline & $0.077^{\mathrm{a}}$ & $0.270^{\mathrm{a}}$ & $0.322^{\mathrm{a}}$ & $0.106^{\mathrm{a}}$ & $0.666^{\mathrm{a}}$ & $0.575^{\mathrm{a}}$ & $1.296^{\mathrm{a}}$ & $0.479^{\mathrm{a}}$ \\
\hline & $0.050^{\mathrm{b}}$ & $0.293^{\mathrm{a}}$ & $0.378^{\mathrm{a}}$ & $0.056^{\mathrm{c}}$ & $1.497^{\mathrm{a}}$ & $0.539^{\mathrm{a}}$ & $1.372^{\mathrm{a}}$ & $0.573^{\mathrm{a}}$ \\
\hline \multirow[t]{3}{*}{$d_{\mathrm{jj}}$} & $0.156^{\mathrm{a}}$ & -0.063 & $0.231^{\mathrm{a}}$ & $0.151^{\mathrm{c}}$ & $-0.261^{a}$ & 0.119 & $0.191^{b}$ & $-0.455^{a}$ \\
\hline & $0.198^{\mathrm{a}}$ & $-0.111^{\mathrm{a}}$ & $0.616^{\mathrm{a}}$ & $0.380^{\mathrm{a}}$ & $0.850^{\mathrm{a}}$ & $-0.414^{a}$ & $-1.221^{\mathrm{a}}$ & $0.304^{\mathrm{a}}$ \\
\hline & $0.194^{\mathrm{a}}$ & $0.342^{\mathrm{a}}$ & $0.693^{\mathrm{a}}$ & $0.897^{\mathrm{a}}$ & $2.051^{\mathrm{a}}$ & $-0.781^{a}$ & $-1.590^{a}$ & $0.610^{\mathrm{a}}$ \\
\hline \multirow[t]{3}{*}{$b_{\mathrm{jj}}$} & $0.960^{\mathrm{a}}$ & $0.837^{\mathrm{a}}$ & $0.897^{\mathrm{a}}$ & $0.695^{\mathrm{a}}$ & $0.648^{\mathrm{a}}$ & $0.436^{\mathrm{a}}$ & $0.760^{\mathrm{a}}$ & $-0.271^{\mathrm{a}}$ \\
\hline & $0.985^{\mathrm{a}}$ & $0.964^{\mathrm{a}}$ & $0.899^{a}$ & $0.954^{\mathrm{a}}$ & $0.651^{\mathrm{a}}$ & $0.857^{\mathrm{a}}$ & $0.148^{\mathrm{a}}$ & $0.899^{\mathrm{a}}$ \\
\hline & $0.994^{\mathrm{a}}$ & $0.957^{\mathrm{a}}$ & $0.904^{\mathrm{a}}$ & $0.904^{\mathrm{a}}$ & $0.224^{\mathrm{a}}$ & $0.839^{\mathrm{a}}$ & $0.0821^{\mathrm{b}}$ & $0.861^{\mathrm{a}}$ \\
\hline
\end{tabular}

Notes: ${ }^{a}$ Significance at the $1 \%$ significance levels

${ }^{\mathrm{b}}$ Significance at the $5 \%$ significance levels

c Significance at the $10 \%$ significance levels 
Table 4a. Maximum-likelihood Estimates of Restricted BEKK VECM-GARCH Models (cont.)

\begin{tabular}{|c|c|c|c|c|c|c|c|c|}
\hline & P_C2 & S_M1 & S_M2 & S_Q1 & S_Q2 & S_Q3 & S_C1 & S_C2 \\
\hline & $(\mathrm{T} / \mathrm{C})$ & $(\mathrm{T} / \mathrm{C})$ & $(\mathrm{T} / \mathrm{C})$ & $(\mathrm{T} / \mathrm{C})$ & $(\mathrm{T} / \mathrm{C})$ & $(\mathrm{T} / \mathrm{C})$ & $(\mathrm{T} / \mathrm{C})$ & $(\mathrm{T} / \mathrm{C})$ \\
\hline & (Futures) & (Futures) & (Futures) & (Futures) & (Futures) & (Futures) & (Futures) & (Futures) \\
\hline & (Options) & (Options) & (Options) & (Options) & (Options) & (Options) & (Options) & (Options) \\
\hline \multicolumn{9}{|c|}{ Panel A: Conditional mean parameters } \\
\hline \multirow[t]{3}{*}{ ect1 } & $-0.001^{c}$ & $-0.010^{\mathrm{a}}$ & $-0.016^{a}$ & $-0.010^{\mathrm{a}}$ & $0.0004^{b}$ & 0.001 & $0.001^{\mathrm{a}}$ & $-0.004^{a}$ \\
\hline & 0.001 & -0.0004 & $-0.012^{b}$ & 0.002 & $0.002^{\mathrm{a}}$ & $0.009^{a}$ & $0.001^{\mathrm{b}}$ & -0.0008 \\
\hline & $0.003^{b}$ & $-0.016^{\mathrm{b}}$ & $-0.012^{a}$ & 0.001 & $0.008^{\mathrm{a}}$ & $0.018^{\mathrm{a}}$ & $0.003^{a}$ & 0.000 \\
\hline \multirow[t]{3}{*}{ ect2 } & - & $0.008^{c}$ & $0.014^{\mathrm{a}}$ & -0.003 & - & - & - & - \\
\hline & - & -0.005 & -0.003 & -0.010 & - & - & - & - \\
\hline & - & $0.164^{a}$ & $0.191^{a}$ & $0.167^{a}$ & - & - & - & - \\
\hline \multirow[t]{3}{*}{ T/C (lag 1) } & $1.070^{\mathrm{a}}$ & $0.834^{\mathrm{a}}$ & $0.676^{\mathrm{a}}$ & $0.860^{\mathrm{a}}$ & $0.888^{\mathrm{a}}$ & $0.880^{\mathrm{a}}$ & $0.857^{a}$ & $0.878^{a}$ \\
\hline & $0.122^{a}$ & $0.858^{\mathrm{a}}$ & $0.321^{\mathrm{a}}$ & $0.311^{\mathrm{a}}$ & 0.028 & $0.370^{\mathrm{a}}$ & $0.104^{c}$ & $0.134^{b}$ \\
\hline & $0.302^{\mathrm{a}}$ & 0.218 & $0.286^{\mathrm{a}}$ & 0.003 & $0.114^{c}$ & $0.332^{\mathrm{a}}$ & $-0.475^{\mathrm{a}}$ & 0.046 \\
\hline \multirow[t]{3}{*}{ Futures (lag 1) } & $0.195^{\mathrm{a}}$ & $0.023^{c}$ & $-0.023^{b}$ & -0.008 & $0.018^{b}$ & 0.023 & $0.098^{\mathrm{a}}$ & $-0.064^{a}$ \\
\hline & $0.304^{a}$ & $0.276^{\mathrm{a}}$ & $0.421^{\mathrm{a}}$ & $0.404^{a}$ & $0.078^{c}$ & $0.086^{b}$ & $0.401^{\mathrm{a}}$ & $0.248^{\mathrm{a}}$ \\
\hline & $0.759^{a}$ & $0.451^{\mathrm{a}}$ & $0.439^{a}$ & $0.439^{a}$ & 0.006 & $0.360^{\mathrm{a}}$ & $0.579^{a}$ & $0.548^{a}$ \\
\hline \multirow[t]{3}{*}{ Options (lag 1) } & $0.015^{\mathrm{a}}$ & -0.002 & -0.003 & $-0.008^{a}$ & $-0.014^{c}$ & $-0.018^{c}$ & -0.007 & -0.005 \\
\hline & 0.008 & $-0.017^{c}$ & $-0.061^{a}$ & -0.018 & $0.030^{\mathrm{b}}$ & -0.022 & 0.002 & -0.009 \\
\hline & $-0.137^{a}$ & -0.025 & $-0.069^{c}$ & -0.043 & $0.072^{b}$ & $-0.207^{a}$ & -0.073 & $-0.092^{b}$ \\
\hline \multirow[t]{3}{*}{ T/C (lag 2) } & $-0.223^{a}$ & 0.0580 & $0.250^{\mathrm{a}}$ & $0.152^{\mathrm{a}}$ & -0.002 & 0.0231 & -0.004 & $0.139^{\mathrm{a}}$ \\
\hline & $-0.136^{a}$ & $-0.561^{a}$ & $-0.327^{a}$ & $-0.330^{\mathrm{a}}$ & 0.032 & -0.081 & $-0.158^{a}$ & $-0.119^{b}$ \\
\hline & $-0.287^{a}$ & -0.051 & $-0.363^{a}$ & $-0.389^{b}$ & $-0.327^{a}$ & -0.162 & 0.0134 & 0.0176 \\
\hline \multirow[t]{3}{*}{ Futures (lag 2) } & -0.026 & -0.007 & $-0.027^{a}$ & -0.006 & $-0.021^{a}$ & -0.015 & -0.008 & $-0.102^{a}$ \\
\hline & $-0.115^{a}$ & -0.065 & -0.006 & 0.009 & $-0.251^{a}$ & -0.049 & $-0.081^{b}$ & -0.049 \\
\hline & $-0.377^{a}$ & $-0.118^{b}$ & -0.090 & -0.024 & $-0.081^{b}$ & -0.060 & -0.016 & $-0.306^{a}$ \\
\hline \multirow[t]{3}{*}{ Options (lag 2) } & 0.004 & -0.001 & -0.001 & -0.006 & $-0.014^{c}$ & -0.006 & -0.003 & $-0.007^{c}$ \\
\hline & -0.0004 & -0.009 & -0.029 & -0.028 & $-0.030^{c}$ & $-0.0478^{a}$ & $-0.011^{a}$ & $-0.019^{a}$ \\
\hline & $0.104^{\mathrm{a}}$ & -0.001 & -0.044 & -0.048 & $-0.220^{\mathrm{a}}$ & $-0.118^{c}$ & 0.0125 & 0.0073 \\
\hline \multirow[t]{3}{*}{ Ratio (lag 1) } & 0.0001 & 0.0001 & $0.0003^{a}$ & $-0.0003^{b}$ & -0.0001 & -0.0001 & $-0.0002^{b}$ & 0.0001 \\
\hline & 0.0002 & -0.0004 & -0.001 & -0.0003 & $-0.002^{a}$ & $0.002^{\mathrm{a}}$ & -0.0001 & 0.000 \\
\hline & 0.0005 & $-0.002^{\mathrm{a}}$ & 0.001 & 0.000 & -0.0002 & $0.002^{\mathrm{a}}$ & -0.0001 & $0.001^{\mathrm{a}}$ \\
\hline \multicolumn{9}{|l|}{ Wald Test } \\
\hline Futures $\rightarrow \mathrm{T} / \mathrm{C}$ & $39.10^{\mathrm{a}}$ & 1.04 & $9.15^{\mathrm{a}}$ & $6.46^{\mathrm{b}}$ & 1.03 & $4.68^{c}$ & 3.25 & 2.49 \\
\hline Options $\rightarrow \mathrm{T} / \mathrm{C}$ & $5.01^{c}$ & 0.46 & 0.18 & 0.71 & 0.95 & 1.76 & 0.37 & 2.61 \\
\hline Joint $\rightarrow$ T/C & $52.81^{\mathrm{a}}$ & 1.30 & $10.55^{\mathrm{b}}$ & $8.78^{c}$ & 2.25 & 6.86 & 3.88 & 5.84 \\
\hline T/C $\rightarrow$ Futures & $12.85^{\mathrm{a}}$ & $18.44^{\mathrm{a}}$ & $10.87^{a}$ & $15.35^{\mathrm{a}}$ & 2.52 & $5.78^{c}$ & 3.28 & 0.42 \\
\hline Options $\rightarrow$ Futures & $3.45^{\mathrm{a}}$ & 2.55 & 1.36 & 3.12 & 1.28 & 0.47 & 2.62 & $5.6^{c}$ \\
\hline Joint $\rightarrow$ Futures & $15.69^{\mathrm{a}}$ & $21.43^{\mathrm{a}}$ & $12.48^{\mathrm{b}}$ & $17.23^{\mathrm{a}}$ & 3.82 & 6.25 & 5.71 & 6.25 \\
\hline $\mathrm{T} / \mathrm{C} \rightarrow$ Options & $7.22^{\mathrm{a}}$ & 0.96 & 1.03 & $4.94^{c}$ & 0.08 & 0.63 & 3.79 & 1.12 \\
\hline Futures $\rightarrow$ Options & $16.83^{a}$ & 0.92 & $4.72^{c}$ & $12.62^{\mathrm{a}}$ & $12.22^{\mathrm{a}}$ & $46.68^{a}$ & $49.35^{\mathrm{a}}$ & $26.55^{\mathrm{a}}$ \\
\hline Joint $\rightarrow$ Options & $32.36^{\mathrm{a}}$ & 2.49 & 6.14 & $18.79^{a}$ & $12.52^{\mathrm{b}}$ & $47.65^{\mathrm{a}}$ & $49.58^{a}$ & $26.94^{a}$ \\
\hline \multicolumn{9}{|c|}{ Panel B: Conditional variance parameters } \\
\hline \multirow[t]{3}{*}{$a_{\mathrm{jj}}$} & $4.1 \mathrm{e}-05^{\mathrm{a}}$ & $3.52 \mathrm{e}-05^{\mathrm{b}}$ & $1.8 \mathrm{e}-05^{\mathrm{a}}$ & $4.9 \mathrm{e}-06^{\mathrm{a}}$ & $1.3 \mathrm{e}-06^{\mathrm{a}}$ & $1.63 \mathrm{e}-06^{\mathrm{a}}$ & $1.61 \mathrm{e}-06^{\mathrm{a}}$ & $6.53 \mathrm{e}-06^{\mathrm{a}}$ \\
\hline & $2.79 \mathrm{e}-06^{\mathrm{a}}$ & $2.78 \mathrm{e}-05^{\mathrm{a}}$ & $0.000167^{a}$ & $0.000335^{\mathrm{a}}$ & $8.43 \mathrm{e}-06^{\mathrm{a}}$ & $9.05 \mathrm{e}-06^{\mathrm{a}}$ & $4.69 \mathrm{e}-06^{\mathrm{a}}$ & $9.3 e-07^{a}$ \\
\hline & 2.14E-06 & $0.000294^{\mathrm{a}}$ & $6.95 \mathrm{e}-05^{\mathrm{a}}$ & $9.13 \mathrm{e}-05^{\mathrm{a}}$ & $-2.48 \mathrm{E}-06$ & $-2.51 \mathrm{E}-06$ & $1.05 \mathrm{E}-06$ & $-1.15 \mathrm{E}-06$ \\
\hline \multirow[t]{3}{*}{$c_{\mathrm{jj}}$} & $0.672^{\mathrm{a}}$ & 0.1727 & $1.038^{\mathrm{a}}$ & $0.769^{\mathrm{a}}$ & $0.167^{\mathrm{a}}$ & $-0.426^{\mathrm{a}}$ & $0.251^{\mathrm{a}}$ & $0.751^{\mathrm{a}}$ \\
\hline & $-0.137^{a}$ & 0.0222 & $0.180^{\mathrm{a}}$ & $0.172^{\mathrm{b}}$ & $0.860^{\mathrm{a}}$ & 0.048 & $0.390^{\mathrm{a}}$ & $0.235^{\mathrm{a}}$ \\
\hline & $-0.381^{a}$ & 0.0114 & 0.056 & $0.090^{\mathrm{a}}$ & $1.121^{\mathrm{a}}$ & $0.212^{\mathrm{a}}$ & $0.692^{\mathrm{a}}$ & $0.514^{a}$ \\
\hline \multirow[t]{3}{*}{$d_{\mathrm{jj}}$} & $0.354^{\mathrm{a}}$ & $-0.202^{b}$ & 0.065 & 0.0588 & $-0.708^{a}$ & $-0.583^{a}$ & $0.678^{a}$ & 0.024 \\
\hline & $0.257^{\mathrm{a}}$ & $-0.257^{a}$ & $0.791^{a}$ & $-0.371^{b}$ & 0.127 & $-0.727^{a}$ & $-0.094^{c}$ & $-0.248^{a}$ \\
\hline & $0.607^{a}$ & $-2.25^{\mathrm{a}}$ & $1.181^{\mathrm{a}}$ & $-1.25^{\mathrm{a}}$ & $0.438^{a}$ & $-0.749^{a}$ & $-0.543^{a}$ & $-0.454^{a}$ \\
\hline \multirow[t]{3}{*}{$b_{\mathrm{jj}}$} & $0.410^{\mathrm{a}}$ & 0.418 & 0.094 & $0.733^{a}$ & $0.907^{a}$ & $0.882^{\mathrm{a}}$ & $0.892^{\mathrm{a}}$ & $0.721^{\mathrm{a}}$ \\
\hline & $0.966^{\mathrm{a}}$ & $0.963^{\mathrm{a}}$ & $0.728^{a}$ & $0.554^{a}$ & $0.839^{a}$ & $0.897^{a}$ & $0.918^{a}$ & $0.965^{\mathrm{a}}$ \\
\hline & $0.906^{\mathrm{a}}$ & $0.604^{a}$ & $0.804^{\mathrm{a}}$ & $0.760^{\mathrm{a}}$ & $0.762^{\mathrm{a}}$ & $0.902^{\mathrm{a}}$ & $0.847^{\mathrm{a}}$ & $0.911^{\mathrm{a}}$ \\
\hline
\end{tabular}


Table 4b. Maximum-likelihood estimates of restricted BEKK VAR-GARCH Models

\begin{tabular}{|c|c|c|c|c|c|}
\hline & C_M1 & C_Q1 & $\mathrm{C}_{-} \mathbf{Q 2}$ & $\mathrm{C}_{-} \mathbf{Q 3}$ & P_M1 \\
\hline & $(\mathrm{T} / \mathrm{C})$ & $(\mathrm{T} / \mathrm{C})$ & $(\mathrm{T} / \mathrm{C})$ & $(\mathrm{T} / \mathrm{C})$ & $(\mathrm{T} / \mathrm{C})$ \\
\hline & (Futures) & (Futures) & (Futures) & (Futures) & (Futures) \\
\hline & (Options) & (Options) & (Options) & (Options) & (Options) \\
\hline \multicolumn{6}{|c|}{ Panel A: Conditional mean parameters } \\
\hline \multirow[t]{3}{*}{ T/C (lag 1) } & $0.539^{a}$ & $0.574^{\mathrm{a}}$ & $0.660^{\mathrm{a}}$ & $0.634^{\mathrm{a}}$ & $0.867^{a}$ \\
\hline & -0.007 & $-0.132^{a}$ & $-0.133^{a}$ & $-0.049^{a}$ & $0.133^{a}$ \\
\hline & $-0.064^{a}$ & $-0.178^{a}$ & $-0.125^{a}$ & $-0.064^{a}$ & $0.134^{\mathrm{a}}$ \\
\hline \multirow[t]{3}{*}{ Futures (lag 1) } & $0.362^{\mathrm{a}}$ & $0.207^{a}$ & 0.051 & $0.242^{\mathrm{a}}$ & $0.052^{\mathrm{a}}$ \\
\hline & $0.421^{\mathrm{a}}$ & $0.340^{\mathrm{a}}$ & -0.087 & $0.057^{\mathrm{a}}$ & $0.211^{\mathrm{a}}$ \\
\hline & $0.618^{a}$ & $0.443^{\mathrm{a}}$ & 0.068 & $0.068^{\mathrm{a}}$ & $0.675^{a}$ \\
\hline \multirow[t]{3}{*}{ Options (lag 1) } & $-0.053^{a}$ & -0.008 & 0.082 & $0.145^{\mathrm{a}}$ & $-0.004^{b}$ \\
\hline & $-0.141^{a}$ & $-0.239^{a}$ & 0.111 & $0.038^{\mathrm{a}}$ & $-0.080^{\mathrm{a}}$ \\
\hline & $-0.249^{a}$ & $-0.316^{a}$ & -0.033 & $0.051^{\mathrm{a}}$ & $-0.351^{a}$ \\
\hline \multirow[t]{3}{*}{ Ratio (lag 1) } & 0.001 & $0.0026^{\mathrm{a}}$ & 0.0009 & 0.0014 & -0.0001 \\
\hline & $-0.002^{a}$ & $0.0055^{\mathrm{a}}$ & $0.0103^{a}$ & $0.0036^{\mathrm{a}}$ & $-0.003^{a}$ \\
\hline & $0.001^{\mathrm{c}}$ & $0.0063^{a}$ & $0.0104^{a}$ & $0.0057^{a}$ & $-0.003^{a}$ \\
\hline \multicolumn{6}{|l|}{ Wald Test } \\
\hline Futures $\rightarrow$ T/C & $88.04^{a}$ & $18.83^{a}$ & 2.11 & $37.59^{a}$ & $65.71^{a}$ \\
\hline Options $\rightarrow \mathrm{T} / \mathrm{C}$ & 2.47 & 1.93 & 1.18 & $44.04^{a}$ & 1.75 \\
\hline Joint $\rightarrow \mathrm{T} / \mathrm{C}$ & $144^{\mathrm{a}}$ & $70.15^{a}$ & $33.00^{\mathrm{a}}$ & $70.3^{a}$ & $86.2^{\mathrm{a}}$ \\
\hline T/C $\rightarrow$ Futures & $8.92^{a}$ & $3.02^{c}$ & $8.79^{a}$ & $6.58^{a}$ & 0.01 \\
\hline Options $\rightarrow$ Futures & $4.67^{a}$ & 0.03 & 0.13 & 0.54 & $4.78^{\mathrm{b}}$ \\
\hline Joint $\rightarrow$ Futures & $12.93^{\mathrm{a}}$ & 3.04 & $9.07^{b}$ & $6.85^{\mathrm{b}}$ & $4.92^{c}$ \\
\hline $\mathrm{T} / \mathrm{C} \rightarrow$ Options & $4.48^{b}$ & $4.35^{\mathrm{b}}$ & $13.34^{a}$ & $10.72^{a}$ & $3.57^{c}$ \\
\hline Futures $\rightarrow$ Options & $15.89^{a}$ & $20.41^{a}$ & $12.74^{\mathrm{a}}$ & $5.36^{\mathrm{b}}$ & $9.16^{\mathrm{a}}$ \\
\hline Joint $\rightarrow$ Options & $16.87^{a}$ & $22.31^{a}$ & $23.62^{a}$ & $16.12^{a}$ & $10.42^{\mathrm{a}}$ \\
\hline \multicolumn{6}{|c|}{ Panel B: Conditional variance parameters } \\
\hline \multirow[t]{3}{*}{$a_{\mathrm{jj}}$} & $7.68 \mathrm{e}-05^{\mathrm{a}}$ & $0.0003^{a}$ & $0.001^{a}$ & $0.0004^{a}$ & $1.33 \mathrm{e}-05^{\mathrm{a}}$ \\
\hline & $1.61 \mathrm{E}-05$ & $2.27 \mathrm{e}-05^{\mathrm{a}}$ & $-1.67 \mathrm{e}-06^{\mathrm{a}}$ & $1.98 \mathrm{e}-07^{\mathrm{c}}$ & $8.09 \mathrm{e}-05^{\mathrm{a}}$ \\
\hline & $-0.0001^{\mathrm{a}}$ & $4.14 \mathrm{e}-05^{\mathrm{c}}$ & $2.33 \mathrm{e}-06^{\mathrm{a}}$ & $2.00 \mathrm{E}-07$ & $8.23 \mathrm{e}-05^{\mathrm{a}}$ \\
\hline \multirow[t]{3}{*}{$c_{\mathrm{jj}}$} & $0.160^{\mathrm{a}}$ & $0.303^{\mathrm{a}}$ & $0.836^{\mathrm{a}}$ & $0.579^{\mathrm{a}}$ & $0.573^{a}$ \\
\hline & $0.333^{\mathrm{a}}$ & $0.718^{\mathrm{a}}$ & -0.007 & $2.40 \mathrm{E}-05$ & $0.283^{\mathrm{a}}$ \\
\hline & $0.157^{\mathrm{a}}$ & $1.171^{\mathrm{a}}$ & -0.006 & 0.001 & $0.212^{\mathrm{a}}$ \\
\hline \multirow[t]{3}{*}{$d_{\mathrm{jj}}$} & $0.255^{a}$ & $0.193^{a}$ & 0.006 & 2.07E-06 & $0.198^{b}$ \\
\hline & $0.712^{\mathrm{a}}$ & $1.181^{\mathrm{a}}$ & $0.037^{\mathrm{a}}$ & $1.14 \mathrm{E}-08$ & $0.897^{a}$ \\
\hline & $1.427^{a}$ & $0.733^{\mathrm{a}}$ & $0.066^{\mathrm{a}}$ & 4.60E-08 & $3.569^{\mathrm{a}}$ \\
\hline \multirow[t]{3}{*}{$b_{\mathrm{jj}}$} & $0.956^{\mathrm{a}}$ & $0.887^{a}$ & $0.360^{\mathrm{a}}$ & $0.750^{\mathrm{a}}$ & $0.763^{a}$ \\
\hline & $0.895^{\mathrm{a}}$ & $0.757^{a}$ & $1.001^{\mathrm{a}}$ & $1.001^{\mathrm{a}}$ & $0.873^{\mathrm{a}}$ \\
\hline & $0.850^{a}$ & $0.692^{\mathrm{a}}$ & $1.000^{\mathrm{a}}$ & $1.001^{\mathrm{a}}$ & $0.744^{\mathrm{a}}$ \\
\hline
\end{tabular}

Notes: The significance levels of the coefficient parameters are denoted in Table 4a. 


\subsection{Impulse response analysis}

Generalized Impulse Responses (GIR) functions of a SUR-VAR (when a cointegrating relationship is not established) and of a SUR-VECM (when a cointegrating relationship is established) are next estimated to provide insights about the dynamics of the causality effects between the three investigated markets. Impulse responses measure the reaction of one market (e.g. time-charter) by inducing one standard-deviation shock to the prices of the other market (e.g. freight futures or options).

Figure 2 depicts the impact of a shock on the Capesize market. The graphs on top illustrate the response of time-charter rates (CTC), ${ }^{21}$ those in the middle the response of freight futures prices $(\mathrm{CTF})$, while the lower graphs show the response of freight option prices (CTO) triggered due to a one standard deviation shock in each respective market. We observe the market response for a 10 day-ahead horizon. ${ }^{22}$ The results indicate that Capesize time-charter rates are strongly affected by the shock generated in freight futures and freight options prices irrespective of maturity, with the shock in freight futures having a greater impact. Unreported results corroborate the same pattern for Panamax rates. Moreover, Capesize and Panamax futures (options) prices are affected by a corresponding shock generated in time-charter rates and options (futures) prices irrespective of maturity. However, it appears that the impact of the shock diminishes faster in the freight futures market than in the time-charter market, indicating that the freight futures market can adapt to shocks more rapidly than the underlying freight market. Supramax time-charter rates (untabulated) marginally react to a shock generated in futures prices, and do not affect options prices at all. This may be due to the low liquidity of Supramax freight futures contracts and the negligible liquidity of Supramax freight options. Overall, for all three types of vessels examined, the futures market has stronger effects in the other two markets (time-charter and freight options) than the time-charter market, while the freight options market has the least significant impact. These results indicate that market participants should still rely on freight futures prices to have a view of the underlying freight market, but cannot use freight options markets for price discovery purposes. Therefore, practitioners who collect and analyze new market information on a daily basis should investigate freight futures markets first, as any new information is revealed there, before it is spilled over to the physical time-charter market, and finally to the freight options market.

\footnotetext{
${ }^{21}$ For example, the upper graphs represent the impact of Capesize time-charter rates (CTC) to one standarddeviation shock on near-month futures (CTF_1M), near-month options (CTO_1M), second near-month futures (CTF_2M), second near-month options (CTO_2M), near-quarter futures (CTF_1Q), near-quarter options (CTO_1Q), second near-quarter futures (CTF_2Q), second near-quarter options (CTO_2Q), third near-quarter futures (CTF_3Q), third near-month options (CTO_3Q), near-calendar futures (CTF_1C), near-calendar options (CTO_1C), second near-calendar futures (CTF_2C), and second near-calendar options (CTO_2C).

22 Impulse response results for Panamax and Supramax vessels are available upon request.
} 
Figure 2. Impulse Responses for Capesize Time-charter rates, Futures, and Options Prices 
Response of D(CTC) to Generalized One S.D. Innovations
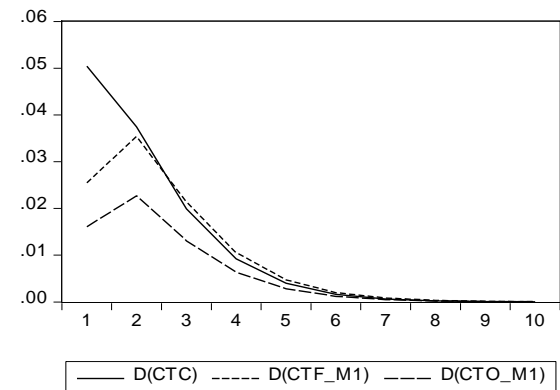

Response of D(CTF_M1) to Generalized One S.D. Innovations

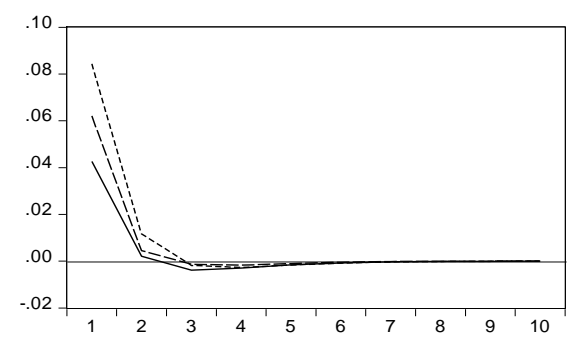

- D(CTC) ----- D(CTF_M1) --- D(CTO_M1)

Response of D(CTO M1) to Generalized One S.D. Innovations

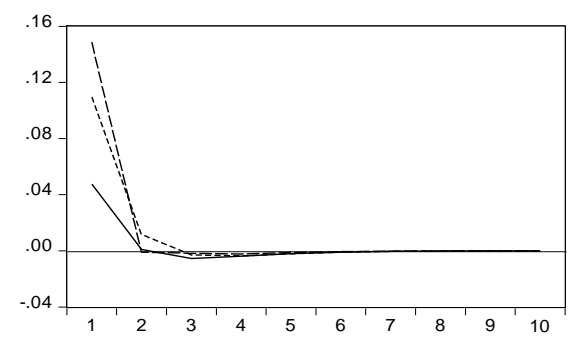

- D(CTC) ----- D(CTF_M1) --_ D(CTO_M1)
Response of D(CTC) to Generalized One S.D. Innovations
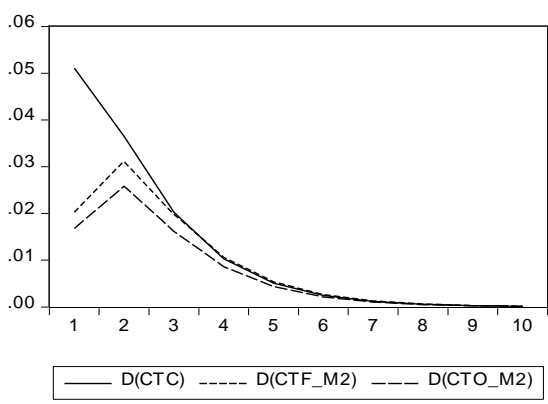

Response of D(CTF M2) to Generalized One S.D. Innovations
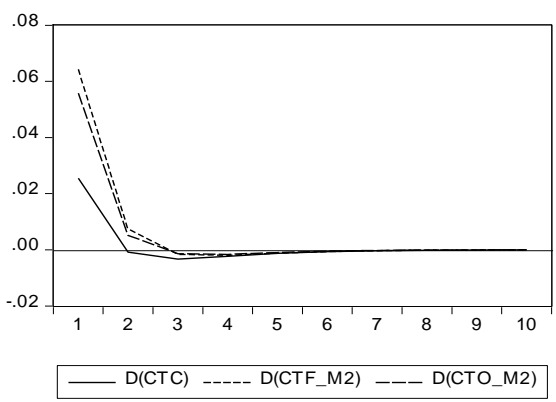

Response of $\mathrm{D}(\mathrm{CTO} M 2)$ to Generalized One S.D. Innovations

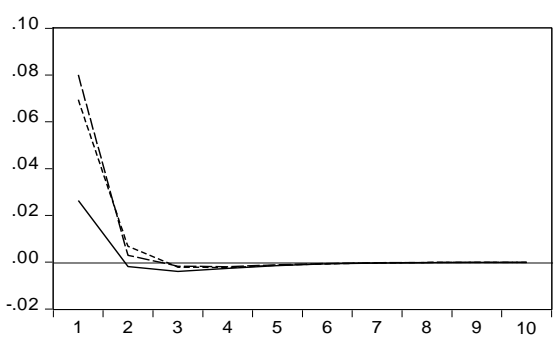

- D(CTC) ----- D(CTF_M2) --- D(CTO_M2)
Response of D(CTC) to Generalized One S.D. Innovations
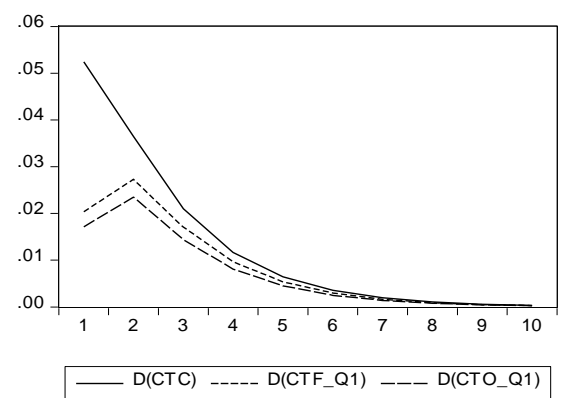

Response of D(CTF Q1) to Generalized One S.D. Innovations
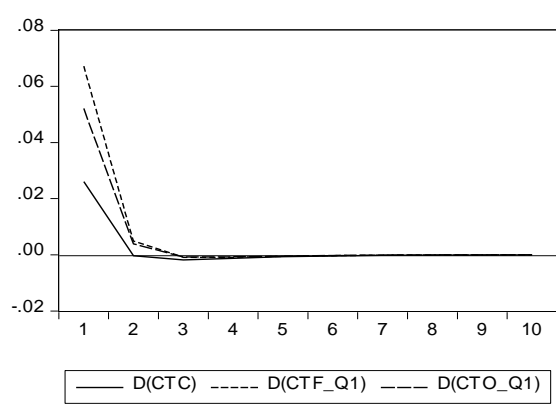

Response of D(CTO Q1) to Generalized One S.D. Innovations

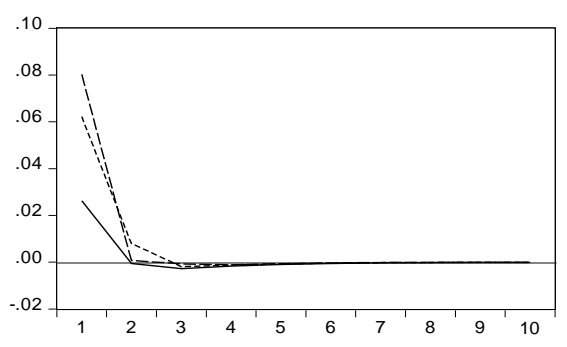

- D(CTC) ----- D(CTF_Q1) --- D(CTO_Q1)
Response of D(CTC) to Generalized One S.D. Innovations

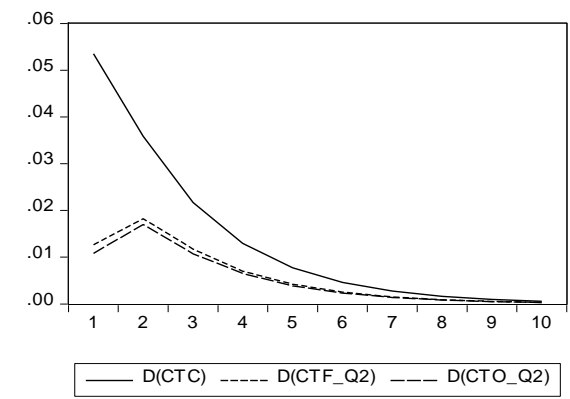

Response of D(CTF_Q2) to Generalized One S.D. Innovations

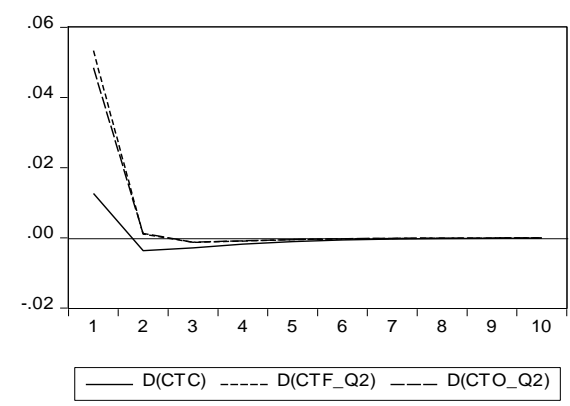

Response of D(CTO Q2) to Generalized One S.D. Innovations

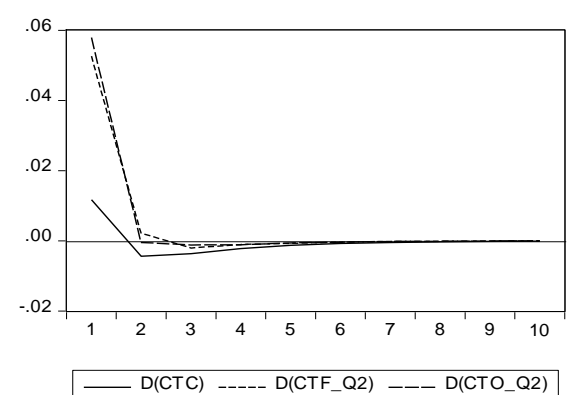


Figure 2. Impulse Responses for Capesize Time-charter rates, Futures and Options Prices (cont.) 
Response of $\mathrm{D}(\mathrm{CTC})$ to Generalized One S.D. Innovation
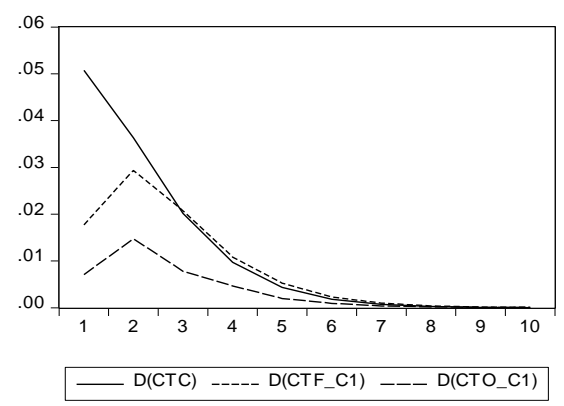

Response of D(CTF_C1) to Generalized One S.D. Innovation
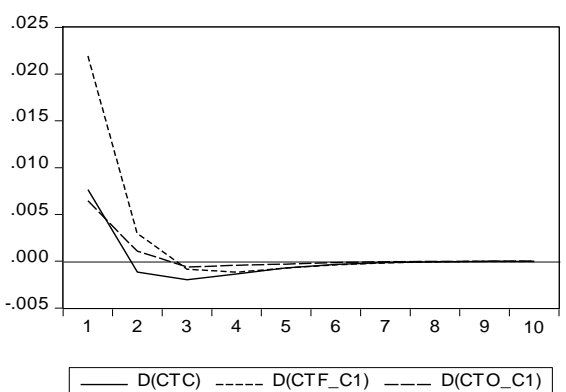

Response of D(CTO C1) to Generalized One S.D. Innovations

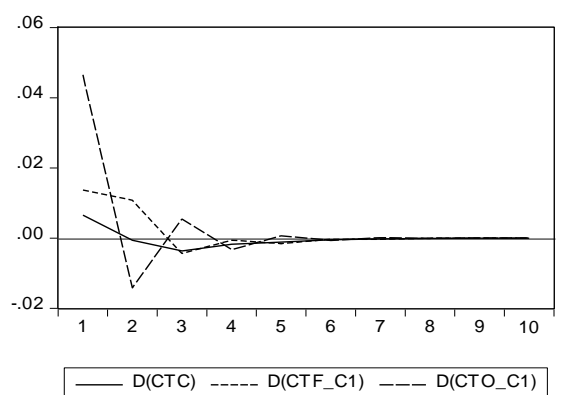

Response of D(CTC) to Generalized One S.D. Innovations
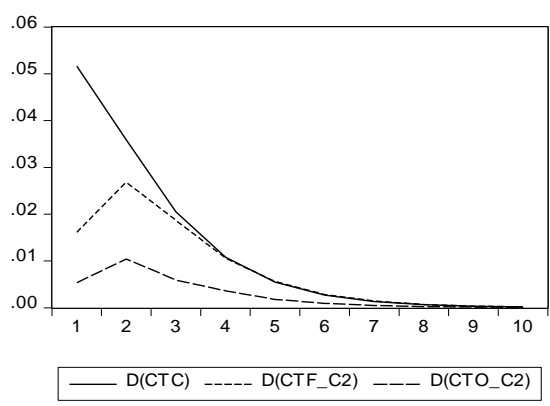

Response of D(CTF C2) to Generalized One S.D. Innovations

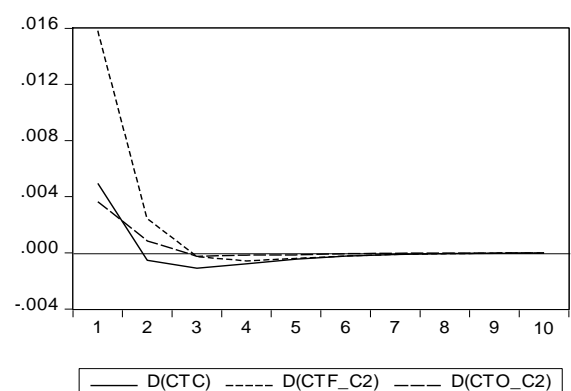

Response of D(CTO C2) to Generalized One S.D. Innovations

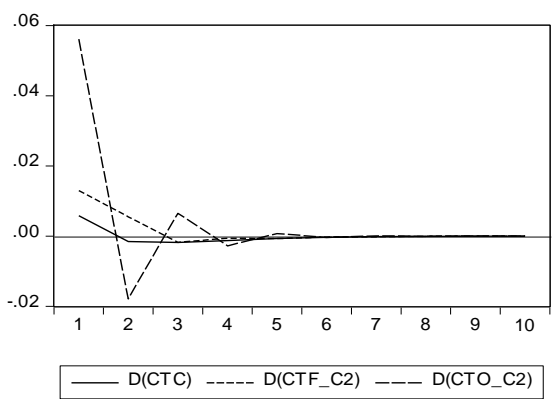

Response of $\mathrm{D}(\mathrm{CTC})$ to Generalized One S.D. Innovations

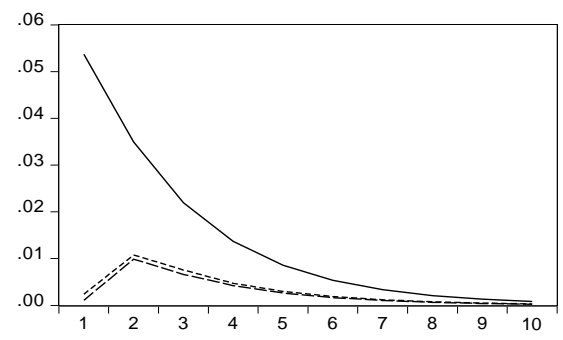

- ${ }^{\mathrm{D}(\mathrm{CTC})}$----- $\mathrm{D}\left(\mathrm{CTF} \mathrm{Q}_{-} \mathrm{Q}\right)$--- D(CTO_Q3)

Response of D(CTF Q3) to Generalized One S.D. Innovations

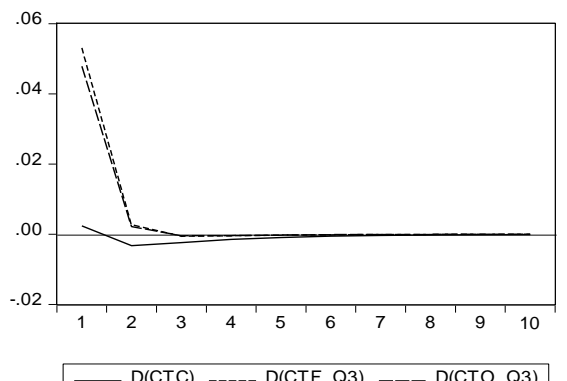

- $\mathrm{D}(\mathrm{CTC})$-.--- $\mathrm{D}\left(\mathrm{CTF} \mathrm{Q}_{-} \mathrm{Q}\right)$--- $\mathrm{D}\left(\mathrm{CTO} \_\mathrm{Q} 3\right)$

Response of D(CTO Q3) to Generalized One S.D. Innovations

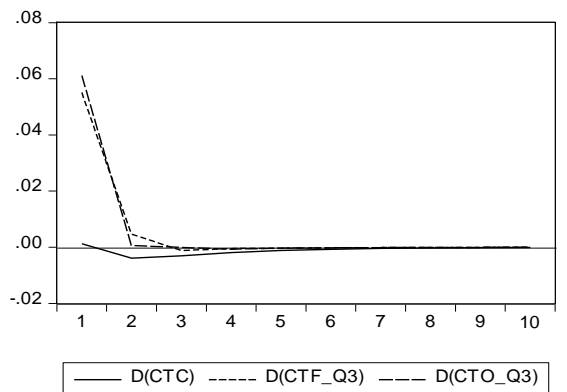




\subsection{Price-trading activities and liquidity measure}

In the literature there is a strong linkage between the trading activities of stock prices with other asset class prices (see for example, Bessembinder, 1992; Bessembinder, et al. 1996; Bessembinder and Seguin, 1993; Lee and Swaminathan, 2000; and Tauchen and Pitts, 1983, among others). Along these lines, in Tables $4 \mathrm{a}$ and $4 \mathrm{~b}$, we observe a strong interaction between freight futures trading activity $\left(\right.$ Ratio $\left._{t-1}\right)$ and freight derivatives (futures and options) prices. Specifically, for Capesize vessels, the lagged ratio of futures trading volume over open interest significantly affects futures and options prices for near to medium distance maturity derivatives contracts (near-month (C_M1), second near-month (C_M2) and near-quarter (C_Q1), second near-quarter (C_Q2) and third near-quarter (C_Q3)), but does not affect time-charter rates at all, except second near-month (C_M2) and near-quarter (C_Q1). For Panamax vessels, the futures trading activities affect near-maturity futures and options contracts only (near-month (P_M1) and near-quarter (P_Q1)). In contrast to Capesize time-charter rates, Panamax timecharter rates are not affected by futures trading activities. Similar to Capesize and Panamax time-charter rates, Supramax time-charter rates are not affected by trading activities futures contracts except second near-month (S_M2), near-quarter (S_Q1) and near-calendar (S_C1) contracts. Supramax freight futures and options prices are only influenced by the trading activities of third near-quarter (S_Q3) futures together. It seems that freight futures trading activities cannot sufficiently explain time-charter rates for either vessel type.

In order to also examine if the options trading activities affect time-charter, futures and options prices, we estimate the ratio of options trading volume over options open interest (from LCH.Clearnet) for 21 models over all different maturities. Only 10 models could be estimated (as the open-interest dropped to zero for all others) with three endogenous variables in each case, adding up to 30 price relationships altogether. Untabulated results indicate that only five (out of 30) price relationships are found to be affected by options trading activities (options prices in C_Q2 and P_M1 maturities, futures prices in C_Q2 and P_Q1 maturities, and timecharter prices for P_M2 maturity). Consequently, it seems that options trading activities are not significantly affecting time-charter, futures or options prices in most cases, which is in line with the rest of our results.

In an attempt to explain the unexpected results relating to the freight options market, Table 5 reports the Amivest liquidity measure results of time-charter, freight futures and options contracts for Capesize, Panamax and Supramax contracts for different maturity periods. Evidently, the liquidity of futures contracts is more than that of options contracts for all vessel types. This may justify the slower reaction of freight options to new market information relative to freight futures, due to the lack of active market practitioners in the freight options market.

It is also observed that near-month futures contracts (F_M1) are more liquid than second nearmaturity futures contracts (F_M2) for Capesize and Supramax vessels, but second nearmaturity futures contracts (F_M2) are more liquid than near-month futures contracts (F_M1) 
for Panamax vessels. Considering quarter-ahead and calendar-ahead contracts, near-quarter futures contracts (F_Q1) are subject to the highest degree of liquidity for all types of vessels. Second near-calendar freight futures (F_C2) contracts are negligible in terms of liquidity for all three types of vessels.

Results indicate that freight futures contracts with higher liquidity produce a strong information transmission compared to freight futures with lower market liquidity. Capesize freight options contracts are the most traded, followed by Panamax options, while Supramax options contracts are the most illiquid. Since Capesize time-charter rates are more volatile than Panamax timecharter rates, shipowners and charterers are more interested in securing long-term freight rates for the Capesize market, leading to a higher liquidity for distant-maturity Capesize futures contracts (than Panamax futures contracts) as observed in Table 5. Overall, the low liquidity of freight options may be the main factor behind the poor price discovery results documented in the previous section. ${ }^{23}$

Table 5 - Amivest Liquidity Ratio for Futures and Options at Different Maturity Periods

\begin{tabular}{|c|c|c|c|c|c|c|c|c|c|c|c|c|c|c|}
\hline & F_M1 & O_M1 & F_M2 & O_M2 & F_Q1 & O_Q1 & F_Q2 & O_Q2 & F_Q3 & O_Q3 & F_C1 & O_C1 & F_C2 & O_C2 \\
\hline CAPE & 1387 & 162 & 989 & 113 & 1433 & 201 & 641 & 211 & 544 & 208 & 914 & 150 & - & 12 \\
\hline PMAX & 1290 & 5 & 1392 & 26 & 1735 & 35 & 593 & 25 & 582 & 31 & 528 & 13 & - & 12 \\
\hline SUPRA & 417 & - & 373 & - & 474 & - & 272 & - & 231 & - & 195 & - & - & - \\
\hline
\end{tabular}

Notes: CAPE, PMAX and SUPRA represents Capesize, Panamax and Supramax markets, respectively. Futures and options contract maturities are as defined in Table 1. The table reports the liquidity ratio of freight futures and options markets for various maturities for the three vessel categories using the Amivest liquidity measure, where a higher liquidity ratio represents higher liquidity in the respective market.

\section{Discussion}

In this study, a system with endogenous time-charter rates, freight futures prices and freight options prices is investigated for the first time. Overall, the results indicate the existence of bidirectional spillovers, both in returns and volatilities, between: (i) freight futures and timecharter markets, (ii) freight futures and freight options markets, and (iii) time-charter and freight options markets, with a stronger information flow reported from the former market to the latter in each case. The stronger information flow from the futures market to the timecharter market may be attributed to the higher transaction costs associated with the trading of physical time-charter contracts, contributing to a slower assimilation of new information into prices. As indicated by the Amivest liquidity measure, the stronger information flow from the futures market to the freight options market is partially driven by the lower liquidity of the latter, resulting in slower incorporation of new market information. Moreover, the freight

\footnotetext{
${ }^{23}$ In order to verify that there is no possible measurement bias to the Amivest ratio, similar to the one in the Amihud ratio, we also re-estimated the Amivest ratio based on a weekly sample period and the (untabulated) results are qualitatively the same; that is, options liquidity is significantly lower than futures liquidity for all three vessel types over the different maturities.
} 
options market receives stronger information spillovers from the physical time-charter market, possibly due to the higher liquidity costs involved.

The coefficients of the lagged return values for physical time-charter rates, futures and options point out that the futures (options) market positively affects the time-charter and options (futures) markets, though the time-charter market negatively affects the futures and options markets. This suggests that during the sample period, freight derivatives market movements tend to increase returns of time-charter rates, but conversely, movements of the physical freight rate market tend to decrease derivatives returns. A possible explanation for these spillover effects is the shipowners' perception of the freight rates mean-reverting properties. It has been documented that freight rates revert back to their long-run mean levels (see for example, Greenwood and Hanson, 2013). Freight rate (and freight futures) prices are determined by market agents' expectations, rather than by a strict cost-of-carry (no-arbitrage) relationship since freight service is a non-storable commodity. This idiosyncratic feature makes shipowners expect an increase in freight futures prices when time-charter rates are low attesting the meanreverting property of freight rates.

This can stimulate increased investment in assets (ships) at a lower price with a view to gain high returns in the near future from a market turnaround. In turn, such strategies can lead to over-supply of vessels exerting pressure to time-charter rates that remain at low levels, sending negative signals to the derivatives markets. Accordingly, the positive sentiment for an expected improvement in the freight market results in a contango forward curve, where freight derivatives prices are higher than the underlying freight rates, inflating the orderbook of drybulk vessels, and prolonging the downturn in freight rates.

One important implication of our results is that the freight futures market informationally leads the physical time-charter market, and can thus be efficiently used as a price discovery vehicle for dry-bulk freight rates, by attracting participants with both hedging and speculation trading motives. Interestingly, it seems that the freight options market should not be relied upon to serve a price discovery function, as it lags behind both the freight futures and physical timecharter markets. Instead, the freight options market is probably most relevant as a vehicle to match willing buyers and sellers for strategic risk hedging, of which at least one party has an interest in a vessel and/or charterparty. In order to empirically investigate the argument that freight futures are mainly used for trading/speculation, whereas freight options are mainly used for strategic hedging purposes, we follow Alizadeh (2013) and regress the trading volume of freight derivatives (futures and options) contracts over one-period lagged freight market volatility. Untabulated results show that for freight futures contracts, in all three vessel types, there is a weak but statistically significant and negative relationship between trading volume and volatility. This negative relationship could be resulted due to information driven trades by a higher number of traders/speculators in the market (see Alizadeh, 2013). These results are also consistent with Batchelor et al. (2007) where they argue that an increase in FFA market 
volatility lowers market liquidity. In contrast, results show that there is no significant relationship between freight options contracts and freight market volatility, indicating that market participants trade freight options contracts irrespective of the volatility of the freight market for strategic hedging purposes. These new findings for the freight options market, documented here for the first time, can be utilised by shipowners, charterers and investors when making chartering and budgeting decisions, by freight brokers when pricing and quoting freight options prices and premiums, and also by regulators when developing policies for the freight market.

Similar to our main finding that the options market informationally lags behind the spot market, Stephan and Whaley (1990), Chan et al. (1993), Chiang and Fong (2001), and Chan et al. (2002), among other studies in the general finance literature, highlight that options prices fall short of fulfilling their price discovery function, which can be partially driven by the illiquidity of the options markets. More specifically, existing literature suggests that although informed practitioners trade in options markets, they have a preference for using "limit orders". ${ }^{24}$ Essentially, in an illiquid market, informed traders place limit orders at prices which might not reflect the expectations of uniformed traders, making it difficult to attract willing counterparties to trade such options contracts. This restricts informed traders to trade freely and thus disseminate information in an illiquid market, which makes options prices informationally lagging behind physical prices. Hence, despite the high degree of inherent financial leverage offered by the options market, options prices may contain less information than physical prices due to lower market liquidity.

Another reason for the low market liquidity of freight options contracts may be that traditional freight option pricing models are less efficient. A strand of literature posits that freight options prices calculated using the conventional Black 76 model tend to be mispriced compared to using other more contemporary pricing models such as Merton's jump diffusion (see Nomikos et al. 2013, for more details). Due to this mispricing, the freight options market fails to attract investors and hedgers, resulting in lower liquidity which may drive the price discovery function inefficiency. To tackle these problems there is a need for developing more efficient freight options pricing models.

Chiang and Fong (2001) argue that another reason could be that market makers focus on the prices on the more liquid and mature futures market and revise them frequently, whereas prices are only infrequently updated for the less active and mature options market and thus, lag behind (stale). Yet another explanation for our empirical results might lie in the fact that the freight

\footnotetext{
${ }^{24}$ A limit order is an order initiated at a specific price. For a buyer (seller) of an option contract, the order cannot be filled at a price higher (lower) than the limit price. If the limit price cannot be realized, then the order remains open until a suitable counterparty is (ever) found. For example, if a charterer (investor) places an order to buy (sell) 20 Capesize time-charter call options at $\$ 10,000 /$ day at a limit price of $\$ 60 /$ lot then the order will only be filled at $\$ 60$ or lower (higher).
} 
options market is mostly utilised by shipowners and freight buyers for hedging (insurance) purposes, rather than for speculation. In practice, freight options may be held together in conjunction with the underlying assets (i.e. vessels, charterparties or even FFAs) as part of an effective hedging strategy. For example, a shipowner may exit a position in a put freight option when she no longer has an interest in the underlying asset, which would not occur regularly (unless for example a vessel is disposed and the long-term charter is terminated). This could explain the low liquidity of the freight options market and, more importantly, why the apparent information asymmetry has not been exploited by speculators.

A policy implication that follows the failure of the price discovery function of freight options relates to the call for further transparency and regulation in derivatives trades. With the growing market risk, followed by the global financial crisis in 2007-2008, regulatory bodies started intervening to control trade of securities and derivatives. The Dodd-Frank Wall Street Reform and Consumer Protection Act (DFA) adopted since 2010 in the US, the European Markets Infrastructure Regulation (EMIR) adopted in 2012 that follows the standards by the European Securities and Markets Authority (ESMA), and the Markets in Financial Instruments Directive II (MiFID II) adopted in 2014 all aim to reduce systemic risk, improve transparency, and reduce counterparty and operation risks. MIFID II has classified instruments/securities into two main types; (i) liquid products - where both the pre- and post-trading data has to be provided, and (ii) illiquid products - where only the post-trading data has to be provided. As freight derivatives falls under illiquid securities, until now, only post traded data is available and this mainly includes unit price, quantity traded, date and time of trade. Though it complies the regulatory requirement of ESMA, lack of pre-trading quotes and delayed reporting of posttrading information (up to two business days) can possibly generate an unexpected lead-lag relationship between the physical freight rate and the freight options markets, such as the one documented in this study.

Finally, market practitioners could take advantage of the above spillover spillovers between the three investigated markets as follows: (i) for investment strategies: Since freight futures prices react faster to new market information and freight options prices follow with a delay, an increase in futures prices and no increase in options prices indicates that options are underpriced, and will thus become more expensive in the near future. Hence, a rational investor would buy an options contract now and sell it when it is expensive. Further, an increase in the volatility of futures prices, indicates that the time-charter or freight options market volatility will shortly increase. Such long trading strategies can be employed by investors to earn higher returns.

(ii) for financial trading strategies: Similar to the above, shipowners and charterers can take advantage of the delayed reaction of freight options prices in relationship to freight futures prices. Shipowners looking to hedge freight rate fluctuations using options contracts should respond to a decrease in futures prices by buying put options contracts and hold them until 
maturity. This will give shipowners the right to exercise the put options and sell the freight service at a high price and earn gains from the possible decrease of freight rates. The opposite is true for charterers.

(iii) for "traditional" hedging strategies: Since a bullish or bearish market state is first reflected in freight futures prices and is then transmitted to the time-charter rates, shipowners should get into short-term time-charter agreements when there is an increase in futures prices. Conversely, if there is a decrease in futures prices, shipowners should favor long-term time-charter agreements. The opposite is true for charterers (see Axarloglou, et al., 2013). This trading signal stemming from the freight futures market can be utilized to improve chartering performance in anticipation of a volatile shipping business cycle.

\subsection{Economic Significance of the Spillover Effects}

In this study we documented that new market information is first assimilated in the freight futures market, before it is transmitted first in the time-charter market and, subsequently, in the freight options market. In addition to the spillover effects in returns and volatilities between the three respective markets, in this section we also investigate the potential of employing profitable trading strategies based on these findings. To that end, we utilize the information from spillovers in returns and volatilities of the futures market as a combined signal in order to take trading positions in the time-charter (T/C) or freight options markets. Subsequently, the profitability of this trading strategy is assessed taking transaction costs into account (brokerage and clearing fees).

The trading strategies follow the frameworks of both: (a) Wu (2001) and Kavussanos and Visvikis (2014), where due to a "volatility feedback effect" an increase in volatility of the informationally leading market $i$ (freight futures) drives an increase in the volatility of the trailing market $j$ (time-charter or freight options), which in turn causes a decrease in prices (negative returns) in market $j$; and (b) Alizadeh and Nomikos (2007), where the timing of market trading is dictated by a 5-day simple moving average process in returns, in order to capture the market trend over a period of time. Accordingly, we estimate a 5-day simple moving average of returns spillover between market $i$ (freight futures) and market $j$ (timecharter or freight options).

The cross-market trading strategies employed involve utilizing the return and volatility spillovers in Tables $4 \mathrm{a}$ and $4 \mathrm{~b}$ as combined signals to take the following trading positions: 
- Good news - Taking a long position in market $j$ when: (a) there is a decreasing volatility spillover in market $i$, leading to a decrease in the volatility and subsequent increase in prices in market $j$, and (b) there is an increasing moving average of returns in market $i$, leading to an increase in the returns in market $j$.

- Bad news - Taking a short position in market $j$ when: (a) there is an increasing volatility spillover in market $i$, leading to an increase in the volatility and subsequent decrease in prices in market $j$, and (b) there is a decreasing moving average of returns in market $i$, leading to a decrease in the returns in market $j$.

VECM- and VAR-BEKK GARCH models are estimated for an in-sample period (April 2013 to January 2016) with the profitability of a given cross-market trading strategy being evaluated for an out-of-sample setting (February 2016 to Aug 2016) in cases where there is evidence of statistically significant return and volatility spillovers from market $i$ to market $j$. A profitable trading strategy is one that produces a positive return after accounting for transactions costs.

Table 6 presents the aggregate profitability (returns) of each cross-market trading strategy. Overall, the empirical results indicate a positive return in most cases, when taking a position in the trailing time-charter (T/C) or freight options market based on the information received from the leading freight futures market. ${ }^{25}$ Moreover, the results also indicate that trading positions based on information from Capesize freight futures generate higher returns on average relative to trading positions triggered by information from Panamax and Supramax freight futures. This is likely due to the higher liquidity of the Capesize freight futures market; i.e. the higher the liquidity, the stronger the information flow, resulting in higher profitability on average.

Finally, summarizing the trading strategy results of Table 6, it can be seen that out of the 21 cases, taking trading positions in the physical T/C market following good news received from the freight futures market generates 20 profitable cases, whereas taking trading positions in the physical T/C market following bad news generates only 16 profitable cases. Similarly, taking trading positions in the freight options market following good news from the freight futures market generates 15 profitable cases, whereas taking trading positions in the freight options market following bad news generates 14 profitable cases. In general, it seems that good news generates more cases of profitable strategies than bad news, especially from the freight futures

\footnotetext{
${ }^{25}$ However, we note that due to the illiquidity of the freight options market, one limitation here is that if a single options trade could potentially "move" the market and render these freight options strategies unsustainable.
} 
to the time-charter market. This is in line with the general investment sentiment that investors delay entering in a trading strategy until "good news" arrive in the market, leading to a higher expectation for profits. ${ }^{26}$

It is interesting to observe that the freight options market by reacting slower to new market information than the physical T/C market, generates less profitable trading cases than the physical market, when using information from the freight futures market. This result could be explained by the more pronounced market frictions in the freight options market, such as, low market liquidity, and higher transaction costs (option premium, brokerage and clearing fees) than in the physical freight market. As discussed above, higher market frictions create slower information absorption. In line with this, the freight options market informationally lags behind the physical T/C market. As the relative transaction costs for freight options trading are higher than for physical T/C trading, trading in the physical T/C market seems to generate more profitable positions - after receiving information from the futures market - compared to trading in the freight options market.

\footnotetext{
26 After also using an asymmetric GJR-GARCH, a volatility leverage effect is evidenced for all three markets; that is, a negative shock is flowed by higher volatility, as compared to a positive shock of the same magnitude. The leverage effect is then used to investigate if high market price volatility in freight futures could lead to high volatility in time-charter and options markets, creating a drop in market prices (bad news) for the latter two markets, and thus, generate profits. The (untabulated) results once again indicate evidence of profitability in the trading strategies.
} 
Table 6. Profitability of Trading Strategies from Economic Cross-Market Spillovers

\begin{tabular}{|c|c|c|c|c|c|c|c|c|}
\hline \multicolumn{9}{|l|}{ Good news } \\
\hline & \multicolumn{8}{|c|}{ Futures to T/C Rates } \\
\hline & $\mathrm{F} \_\mathrm{M} 1 \rightarrow \mathrm{T} / \mathrm{C}$ & $\mathrm{F} \_\mathrm{M} 2 \rightarrow \mathrm{T} / \mathrm{C}$ & F_Q1 $\rightarrow \mathrm{T} / \mathrm{C}$ & F_Q2 $\rightarrow$ T/C & F_Q3 $\rightarrow \mathrm{T} / \mathrm{C}$ & $\mathrm{F} \_\mathrm{C} 1 \rightarrow \mathrm{T} / \mathrm{C}$ & $\mathrm{F} \_\mathrm{C} 2 \rightarrow \mathrm{T} / \mathrm{C}$ & Avg \\
\hline Capesize & 1.675 & 1.451 & 1.848 & 1.232 & -0.022 & 2.134 & 2.141 & 1.494 \\
\hline Panamax & 1.173 & 1.185 & 1.090 & 0.742 & 0.833 & 0.939 & 1.279 & 1.034 \\
\hline \multirow[t]{3}{*}{ Supramax } & 0.300 & 0.379 & 0.441 & 0.382 & 0.451 & 0.080 & 0.122 & 0.308 \\
\hline & \multicolumn{8}{|c|}{ Futures to Options } \\
\hline & F_M1 $\rightarrow$ O_M1 & F_M1 $\rightarrow$ O_M2 & F_M1 $\rightarrow$ O_Q1 & F_M1 $\rightarrow$ O_Q2 & F_M1 $\rightarrow$ O_Q3 & F_M1 $\rightarrow$ O_C1 & F_M1 $\rightarrow$ O_C2 & Avg \\
\hline Capesize & 0.573 & 0.156 & 0.436 & -0.145 & 0.335 & -0.076 & -0.093 & 0.169 \\
\hline Panamax & 1.217 & 0.541 & 0.047 & 0.045 & -0.285 & 0.344 & -0.223 & 0.241 \\
\hline Supramax & 0.027 & 0.054 & -0.088 & 0.121 & 0.064 & 0.007 & 0.098 & 0.040 \\
\hline \multicolumn{9}{|l|}{ Bad news } \\
\hline & \multicolumn{8}{|c|}{ Futures to $\mathrm{T} / \mathrm{C}$ Rates } \\
\hline & F_M1 $\rightarrow \mathrm{T} / \mathrm{C}$ & $\mathrm{F} \_\mathrm{M} 2 \rightarrow \mathrm{T} / \mathrm{C}$ & F_Q1 $\rightarrow \mathrm{T} / \mathrm{C}$ & F_Q2 $\rightarrow \mathrm{T} / \mathrm{C}$ & F_Q3 $\rightarrow$ T/C & $\mathrm{F} \_\mathrm{C} 1 \rightarrow \mathrm{T} / \mathrm{C}$ & $\mathrm{F} \_\mathrm{C} 2 \rightarrow \mathrm{T} / \mathrm{C}$ & Avg \\
\hline Capesize & 0.909 & 0.625 & 0.816 & 1.057 & 0.559 & 0.439 & 0.455 & 0.694 \\
\hline Panamax & 0.203 & 0.208 & 0.146 & -0.175 & -0.090 & 0.030 & 0.024 & 0.050 \\
\hline \multirow[t]{3}{*}{ Supramax } & -0.042 & 0.145 & 0.140 & 0.030 & -0.018 & 0.096 & -0.039 & 0.045 \\
\hline & \multicolumn{8}{|c|}{ Futures to Options } \\
\hline & F_M1 $\rightarrow$ O_M1 & F_M1 $\rightarrow$ O_M2 & F_M1 $\rightarrow$ O_Q1 & F_M1 $\rightarrow$ O_Q2 & F_M1 $\rightarrow$ O_Q3 & F_M1 $\rightarrow$ O_C1 & F_M1 $\rightarrow$ O_C2 & Avg \\
\hline Capesize & 3.881 & 1.675 & 0.828 & -0.312 & 0.537 & 0.149 & 0.018 & 0.968 \\
\hline Panamax & 1.357 & 0.603 & 0.317 & -0.006 & -0.085 & -0.065 & -0.240 & 0.269 \\
\hline Supramax & 0.290 & 0.170 & -0.136 & -0.131 & 0.053 & 0.008 & 0.278 & 0.076 \\
\hline
\end{tabular}

Notes: The table reports the profitability (combined returns) of trading strategies after taking into account the transaction costs (brokerage and clearing fees) involved in taking positions in the time-charter (T/C) and freight options markets, after using information from the freight futures market. The cross-market trading strategies involve taking long (short) positions in either the time-charter or freight options markets based on the good (bad) news signal received from informationally leading futures market. Return and volatility spillovers from Tables $4 \mathrm{a}$ and $4 \mathrm{~b}$ are used as signals to establish the cross-market trading strategies. The transaction cost for the time-charter market is $1.25 \%$ of the economic value of the charter contract, while for the freight options market is $1.5 \%$ of the economic value of the options contract plus $\$ 8$ clearing fee per lot.

\section{Conclusion}

This study examines the spillover effects of time-charter rates, freight futures and options prices, and their association with trading activities and market liquidity of freight futures contracts, for Capesize, Panamax and Supramax vessels. A strong interaction between timecharter rates, freight futures and options prices is documented, which relates to the arrival of new market information. This study contributes to the existing literature as follows: (i) to the best of our knowledge this is the first study to investigate the information spillover of returns and volatilities between time-charter rates, freight futures and freight options markets; (ii) it examines whether the level of information transmission of freight derivatives markets is related to concurrent market conditions, such as trading volume and open interest; (iii) by using a trivariate model that captures the dynamics of all three markets together, it better captures the 
cross-market information spillover mechanisms; and (iv) it examines an emerging derivatives market, which may be less efficient in assimilating new market information into prices than other more mature markets.

Results support the existence of significant information transmissions (both in returns and volatilities) between time-charter rates, freight futures and freight options markets for all vessel types examined. Freight futures prices react faster in assimilating new market information, as there are lower transaction costs for futures contracts than in the physical freight market for fixing vessels. In contrast, freight options prices are the slowest to react to new market information, partially due to the high illiquidity of this market, compared to the freight futures market. The results also indicate market liquidity to be the primary factor for the increase in volatility of the investigated markets. Finally, it is found that the spillover results uncovered in this study can generate on average economically profitable trading strategies.

The new spillover effect results, documented for the first time in this study, have important implications for practitioners, as they can help gain a better understanding of the interactions between three related markets. The results can be utilized in hedging and investment strategies, since by observing the informationally leading market practitioners can draw inferences about the future (short-run) direction of the other markets. The volatility interactions between the three related markets can provide an effective risk prediction mechanism, which can enhance investors' decision-making. Finally, the results of this study can act as a benchmark for researchers and regulators to gain a better understanding of the freight derivatives markets. The results for the freight options call for further investigations in that market.

\section{Acknowledgements}

The authors would like to thank the editor and two anonymous reviewers for their comments and recommendations on an earlier version of the paper. Also the authors thank the Baltic Exchange and LCH.Clearnet for providing the data. This study has also helped by the comments of the participants of the following conferences: $6^{\text {th }}$ National Conference of the Financial Engineering and Banking Society (FEBS), 20-21 Dec 2015, Piraeus, Greece; and Annual Conference of International Association of Maritime Economists (IAME), 23-26 Aug 2016, Hamburg, Germany. The responsibility for any remaining errors rests with the authors.

\section{REFERENCES}


Admati, A. R. \& Pfleiderer, P. 1988. A theory of intraday patterns: Volume and price variability. Review of Financial Studies, 1, 3-40.

Alizadeh, A. H. \& Nomikos, N. K. 2007. Investment timing and trading strategies in the sale and purchase market for ships. Transportation Research Part B: Methodological, 41, 126-143.

Alizadeh, A. H. 2013. Trading volume and volatility in the shipping forward freight market. Transportation Research Part E: Logistics and Transportation Review, 49, 250-265.

Alizadeh, A. H., Kappou, K., Tsouknidis, D. \& Visvikis, I. 2015. Liquidity effects and FFA returns in the international shipping derivatives market. Transportation Research Part E: Logistics and Transportation Review, 76, 58-75.

Amihud, Y. 2002. Illiquidity and stock returns: Cross-section and time-series effects. Journal of Financial Markets, 5, 31-56.

Axarloglou, K, Visvikis, I. D. \& Zarkos, S. 2013. The time dimension and value of flexibility in resource allocation: The case of the maritime industry. Transportation Research Part E: Logistics and Transportation Review, 52, 35-48.

Bae, S. C., Kwon, T. H. \& Park, J. W. 2004. Futures trading, spot market volatility, and market efficiency: The case of the Korean index futures markets. Journal of Futures Markets, 24(12), 1195-1228.

Baele, L. 2005. Volatility spillover effects in European equity markets. Journal of Financial and Quantitative Analysis, 40, 373-401.

Banerjee, A., Lumsdaine, R. L. \& Stock, J. H. 1992. Recursive and sequential tests of the unit root and trendbreak hypotheses: Theory and international evidence. Journal of Business \& Economic Statistics, 10, 271-287.

Batchelor, R., Alizadeh, A. H., \& Visvikis, I. 2007. Forecasting spot and forward prices in the international freight market. International Journal of Forecasting 23(1), 101-114.

Bessembinder, H. \& Seguin, P. J. 1993. Price volatility, trading volume, and market depth: Evidence from futures markets. Journal of Financial and Quantitative Analysis, 28, 21-39.

Bessembinder, H. 1992. Systematic risk, hedging pressure, and risk premiums in futures markets. Review of Financial Studies. 5, 637-667.

Bessembinder, H., Chan, K. \& Seguin, P. J. 1996. An empirical examination of information, differences of opinion, and trading activity. Journal of Financial Economics 40, 105-134.

Billio, M. \& Caporin, M. 2009. A generalized dynamic conditional correlation model for portfolio risk evaluation. Mathematics and Computers in Simulation, 79(8), 2566-2578.

Black, F. \& Scholes, M. 1973. The pricing of options and corporate liabilities. Journal of Political Economy, 637654.

Black, F. 1976. The pricing of commodity contracts. Journal of Financial Economics, 3, 167-179.

Caporin, M. \& McAleer, M. 2012. Do we really need both BEKK and DCC? A tale of two multivariate GARCH models. Journal of Economic Surveys, 26(4), 736-751.

Caporin, M. \& McAleer, M., 2008. Scalar BEKK and indirect DCC. Journal of Forecasting, 27(6), 537-549.

Capozza, D. R., Hendershott, P. H. \& Mack, C. 2004. An anatomy of price dynamics in illiquid markets: analysis and evidence from local housing markets. Real Estate Economics, 32, 1-32.

Chakravarty, S., Gulen, H. \& Mayhew, S. 2004. Informed trading in stock and options markets. Journal of Finance, 59, 1235-1257.

Chan, K., Chung, Y. P. \& Fong, W. M., 2002. The informational role of stock and option volume. Review of Financial Studies, 15(4), pp.1049-1075.

Chan, K., Chung, Y. P. \& Johnson, H., 1993. Why option prices lag stock prices: a trading - based explanation. The Journal of Finance, 48(5), pp.1957-1967.

Chelley-Steeley, P. L., Lambertides, N. \& Steeley, J. M., 2015. The effects of non-trading on the illiquidity ratio. Journal of Empirical Finance, 34, pp.204-228.

Chiang, R. \& Fong, W. M. 2001. Relative informational efficiency of cash, futures and options markets: The case of an emerging market. Journal of Banking and Finance, 25, 355-375.

Cooper, S. K., Groth, J. C. \& Avera, W. E. 1985. Liquidity, exchange listing, and common stock performance. Journal of Economics and Business, 37, 19-33.

Curran, M. 1992. Beyond average intelligence, Risk. November, p. 60.

Dickey, D. A. \& Fuller, W. A. 1981. Likelihood ratio statistics for autoregressive time series with a unit root. Econometrica, 49, 1057-1072.

Ehrmann, M., Fratzscher, M. \& Rigobon, R. 2011. Stocks, bonds, money markets and exchange rates: measuring international financial transmission. Journal of Applied Econometrics, 26(6), pp.948-974.

Engle, R. F. 1982. Autoregressive conditional heteroscedasticity with estimates of the variance of United Kingdom inflation. Econometrica, 50, 987-1007.

Engle, R. F. \& Kroner, K. F. 1995. Multivariate simultaneous generalized ARCH. Econometric Theory, 11, 122150. 
Engle, R. F. \& Ng, V. K. 1993. Measuring and testing the impact of news on volatility. The Journal of Finance, 48, 1749-1778.

Fama, E. F. \& French, K. R. 1987. Commodity futures prices: Some evidence on forecast power, premiums, and the theory of storage. Journal of Business, 55-73.

Foucault, T., Pagano, M. \& Röell, A. 2013. Market Liquidity: Theory, evidence, and policy, Oxford University Press.

Greenwood, R. \& Hanson, S. 2013. Waves in ship prices and investment. National Bureau of Economic Research.

Gregory, A.W. \& Hansen, B. E. 1996. Residual-based tests for cointegration in models with regime shifts. Journal of econometrics, 70(1), pp.99-126.

Hasbrouck, J. \& Seppi, D. J. 2001. Common factors in prices, order flows, and liquidity. Journal of Financial Economics, 59, 383-411.

Jarque, C. M. \& Bera, A. K., 1980. Efficient tests for normality, homoscedasticity and serial independence of regression residuals. Economics Letters, 6, 255-259.

Johansen, S. 1988. Statistical analysis of cointegration vectors. Journal of Economic Dynamics and Control, 12, 231-254.

Johansen, S., Mosconi, R. \& Nielsen, B. 2000. Cointegration analysis in the presence of structural breaks in the deterministic trend. Econometrics Journal, 3, 216-249.

Karpoff, J. M. 1987. The relation between price changes and trading volume: A survey. Journal of Financial and Quantitative Analysis, 22, 109-126.

Kavussanos, M. G. 1996. Comparisons of volatility in the dry-cargo ship sector: Spot versus time charters, and smaller versus larger vessels. Journal of Transport Economics and Policy, 67-82.

Kavussanos, M. G. \& Visvikis, I. D. 2004. Market interactions in returns and volatilities between spot and forward shipping freight markets. Journal of Banking and Finance, 28, 2015-2049.

Kavussanos, M. G. \& Visvikis, I. D. 2006a. Derivatives and risk management in shipping. Witherbys Publishing \& Seamanship International, UK, June.

Kavussanos, M. G. \& Visvikis, I. D. 2006b. Shipping freight derivatives: A survey of recent evidence. Maritime Policy and Management, 33, 233-255.

Kavussanos, M. G. \& Visvikis, I. D. 2011. Theory and practice of shipping freight derivatives, Risk Books.

Kavussanos, M. G., Visvikis, I. D., \& Dimitrakopulos, D. N. 2014. Economic Spillovers between Related derivatives markets: The case of commodity and freight markets. Transportation Research Part E: Logistics and Transportation Review, 68, 79-102.

Kemma, A. G. Z. \& Vorst, A. C. F. 1990. A pricing method for options based on average asset values, Journal of Banking and Finance 14, 113-129.

Koekebakker, S., Adland, R. \& Sødal, S. 2007. Pricing freight rate options. Transportation Research Part E: Logistics and Transportation Review, 43, 535-548.

Kwiatkowski, D., Phillips, P. C. B., Schmidt, P. \& Shin, Y. 1992. Testing the null hypothesis of stationarity against the alternative of a unit root. Journal of Econometrics, 54, 159-178.

Lamoureux, C. G. \& Lastrapes, W. D. 1994. Endogenous trading volume and momentum in stock-return volatility. Journal of Business and Economic Statistics, 12, 253-260.

Lee, C. M. C. \& Swaminathan, B. 2000. Price momentum and trading volume. Journal of Finance, 55, 2017-2069.

Levy, E. 1992. Pricing European average rate currency options. Journal of International Money and Finance, 14 474-491.

Ljung, G. M. \& Box, G. E. 1978. On a measure of lack of fit in time series models. Biometrika, 65, 297-303.

Löffler, G. 2005. Avoiding the rating bounce: why rating agencies are slow to react to new information. Journal of Economic Behavior and Organization, 56, 365-381.

Miller, K. D. 1979. The relation between volatility and maturity in futures contracts. R. M. Leuthod (Ed.) Commodity Markets and Futures Prices. Chigago Merchantile Exchange, pp. 25-36.

Milonas, N. T. 1986. Price variability and the maturity effect in futures markets. Journal of Futures Markets, 6, 443-460.

$\mathrm{Ng}$, A. 2000. Volatility spillover effects from Japan and the US to the Pacific-Basin. Journal of International Money and Finance, 19, 207-233.

Nomikos, N. K., Kyriakou, I., Papapostolou, N. C. \& Pouliasis, P. K. 2013. Freight options: Price modelling and empirical analysis. Transportation Research Part E: Logistics and Transportation Review, 51, 82-94.

Oxford Economics, 2015. The economic value of the EU shipping industry - update. A report for the European Community Shipowners' Associations (ECSA), February.

Perron, P. \& Vogelsang, T. J. 1992. Nonstationarity and level shifts eith an application to purchasing power parity. Journal of Business and Economic Statistics, 10, 301-320.

Perron, P. 1989. The great crash, the oil price shock, and the unit root hypothesis. Econometrica: Journal of the Econometric Society, 1361-1401.

Phillips, P. C. \& Perron, P. 1988. Testing for a unit root in time series regression. Biometrika, 75, 335-346. 
Silber, W. L. 1991. Discounts on restricted stock: The impact of illiquidity on stock prices. Financial Analysts Journal, 47, 60-64.

Silvennoinen, A. \& Teräsvirta, T. 2009. Multivariate GARCH models. In Handbook of financial time series (201229), Springer Berlin Heidelberg.

Sloan, R. 1996. Do stock prices fully reflect information in accruals and cash flows about future earnings? Accounting Review, 71, 289-315.

Stephan, J. A. and Whaley, R. E. 1990. Intraday price change and trading volume relations in the stock and stock option markets. The Journal of Finance, 45(1), pp.191-220.

Tauchen, G. E. \& Pitts, M. 1983. The price variability-volume relationship on speculative markets. Econometrica, $51,485-505$.

Turnbull, S. M. \& Wakeman, L. M. 1991. A quick algorithm for pricing European average options. Journal of Financial and Quantitative Analysis, 26, 377-389.

Vogelsang, T. J. \& Perron, P. 1998. Additional tests for a unit root allowing for a break in the trend function at an unknown time. International Economic Review, 39, 1073-1100.

Spreckelsen, C., Mettenheim, H.-J. \& Breitner, M. H. 2014. Spot and freight rate futures in the tanker shipping market: Short-term forecasting with linear and non-linear methods. In: Helber, S., Breitner, M., Rösch, D., Schön, C., Graf Von Der Schulenburg, J.-M., Sibbertsen, P., Steinbach, M., Weber, S. \& Wolter, A. (eds.) Operations Research Proceedings 2012: Selected Papers of the International Annual Conference of the German Operations Research Society (GOR), Leibniz University of Hannover, Germany, September 5-7, 2012. Cham: Springer International Publishing.

Wang, K. L. \& Chen, M. L. 2007. The dynamics in the spot, futures, and call options with basis asymmetries: an intraday analysis in a generalized multivariate GARCH-M MSKST framework. Review of Quantitative Finance and Accounting, 29(4), pp.371-394.

Watanabe, T. 2001. Price volatility, trading volume, and market depth: evidence from the Japanese stock index futures market. Applied Financial Economics, 11(6), pp.651-658.

Wiggins, J. B. 1987. Option values under stochastic volatility: Theory and empirical estimates. Journal of Financial Economics, 19, 351-372.

Wu, G. 2001. The determinants of asymmetric volatility. Review of Financial Studies, 14, 837-859.

Xiao, L. \& Dhesi, G. 2010. Volatility spillover and time varying conditional correlation between the European and US stock markets. Global Economy and Finance Journal, 3, 148-164.

Zhang, J., Zeng, Q. \& Zhao, X. 2014. Forecasting spot freight rates based on forward freight agreement and time charter contract. Applied Economics, 46, 3639-3648.

Zhang, S., Paya, I. \& Peel, D. 2009. Linkages between Shanghai and Hong Kong stock indices. Applied Financial Economics, 19, 1847-1857. 